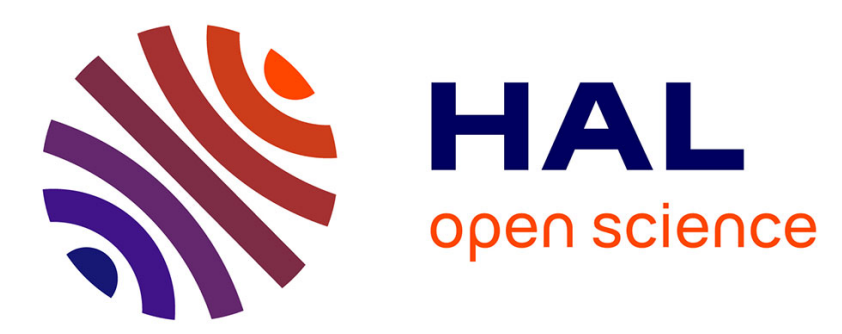

\title{
Similar irradiance-elicited plasticity of leaf in saplings of 12 tropical rainforest tree species with highly different leaf mass to area ratio
}

\author{
Sabrina Coste, Jean-Christophe Roggy, Grégory Sonnier, Erwin Dreyer
}

\section{- To cite this version:}

Sabrina Coste, Jean-Christophe Roggy, Grégory Sonnier, Erwin Dreyer. Similar irradiance-elicited plasticity of leaf in saplings of 12 tropical rainforest tree species with highly different leaf mass to area ratio. Functional Plant Biology, 2010, 37 (4), pp.342-355. 10.1071/FP09119 . hal-01032129

\author{
HAL Id: hal-01032129 \\ https://hal.science/hal-01032129
}

Submitted on 31 May 2020

HAL is a multi-disciplinary open access archive for the deposit and dissemination of scientific research documents, whether they are published or not. The documents may come from teaching and research institutions in France or abroad, or from public or private research centers.
L'archive ouverte pluridisciplinaire HAL, est destinée au dépôt et à la diffusion de documents scientifiques de niveau recherche, publiés ou non, émanant des établissements d'enseignement et de recherche français ou étrangers, des laboratoires publics ou privés. 


\title{
Similar irradiance-elicited plasticity of leaf traits in saplings of 12 tropical rainforest tree species with highly different leaf mass to area ratio
}

\author{
Sabrina Coste ${ }^{\mathrm{A}}$, Jean-Christophe Roggy ${ }^{\mathrm{A}}$, Gregory Sonnier $^{\mathrm{A}}$ and Erwin Dreyer $^{\mathrm{B}, \mathrm{C}}$ \\ AAgroParisTech-ENGREF, INRA, Unité Mixte de Recherches CIRAD-ENGREF-INRA-CNRS 'Ecologie des Forêts de \\ Guyane', Campus Agronomique de Kourou, F 97387 Kourou, Guyane, France. \\ BINRA, Nancy-Université, UMR 1137 'Ecologie et Ecophysiologie Forestières', IFR 110 'Ecosystèmes Forestiers, \\ Agroressources, Biomolécules et Alimentation', F 54280 Champenoux, France. \\ ${ }^{\mathrm{C}}$ Corresponding author. Email: dreyer@nancy.inra.fr
}

\begin{abstract}
Leaf traits of tropical tree species display an important inter-specific diversity, as detected for instance in the large range of values of leaf mass : area ratio (LMA). They also demonstrate a large irradiance-elicited plasticity, but there is still debate whether this plasticity differs among species. To address this question, leaf traits were recorded on saplings from 12 rainforest tree species in French Guiana, grown under approximately 5, 10 and 20\% relative irradiance. Fifteen structural and physiological leaf traits related to photosynthesis were measured. The irradiance-elicited plasticity was quantified using a relative distance plasticity index. A large inter-specific diversity was detected for all leaf traits. A principal component analysis opposed species with a large mass-based photosynthesis, respiration, $\mathrm{N}$ content and photosynthetic nitrogen use efficiency, to species with a large leaf mass : area ratio, LMA. The two pioneer species used in this study displayed the largest photosynthetic capacity (and lowest LMA) and ranked at one end of the species continuum. Relative irradiance affected almost all traits with the exception of mass-based photosynthesis. A weak interaction was found between species and relative irradiance and the species ranking was maintained among relative irradiance treatments for the majority of the traits. A principal component analysis of the values of relative-distance plasticity index failed to reveal any consistent patterns of traits or species. We concluded that irradiance-elicited plasticity of leaf traits was similar among species irrespective of LMA and successional status, despite the occurrence of a large inter-specific diversity for the investigated traits.
\end{abstract}

Additional keywords: functional diversity, light availability, photosynthetic nitrogen use efficiency, photosynthetic capacity, tropical rainforest.

\section{Introduction}

In tropical rainforests, irradiance below the canopy is the most important factor influencing species recruitment, as deep shade severely limits growth and survival of understory species and results in death of the less shade-tolerant ones (Bazzaz and Pickett 1980; Fetcher et al. 1983). The phenotypic response of trees to the shaded-end of the environmental gradients encountered in the understory (below 30\% full external irradiance, Poorter and Werger 1999; Bloor and Grubb 2003) is particularly relevant to survival at low irradiance and recruitment of new generations. In this respect, traits controlling photosynthetic carbon assimilation may be of importance for the shade tolerance of the species.

Leaves of tropical forest trees display a large diversity of structural (e.g. thickness, density and mass : area ratio, LMA) and physiological traits (e.g. light-saturated net $\mathrm{CO}_{2}$ assimilation rates, $A_{\text {sat }}$ and carbon isotope composition, $\delta^{13} \mathrm{C}$ ) even among co-occurring species (Popma et al. 1992; Poorter et al. 1995; Rozendaal et al. 2006; Bonal et al. 2007). Leaf traits seem to follow a universal scheme of resource management and a global 'leaf economic spectrum' was described based on the tight coordination between six traits (LMA; leaf lifespan, LLS; leaf $\mathrm{N}$ per unit mass, $N_{\mathrm{m}}$; mass-based photosynthetic capacity, $A_{\text {mass }}$; mass-based dark respiration rate, $R_{\text {dmass }}$ and leaf $\mathrm{P}$ per unit mass, Wright et al. 2004). The spectrum ranks species and leaf forms along a gradient ranging from rapid to slow returns of the investment of nutrients and dry mass into leaves. This suggests a trade-off between (i) leaf traits that enable a rapid assimilation of C-resources ( $N_{\mathrm{m}}$, photosynthetic capacity, respiration) and (ii) leaf traits that favour carbon and nutrient conservation (LMA and LLS). For instance, a tight correlation is usually observed between leaf $\mathrm{N}$ and photosynthetic capacity at a broad scale (Reich and Walters 1994; Reich et al. 1999; Wright et al. 2004). Nevertheless, a significant inter-specific variability still remains in photosynthetic nitrogen use efficiency (PNUE, Pons and Pearcy 1994; Poorter and Evans 1998). PNUE tends to be smaller in species with large LMA, i.e. a smaller fraction of leaf $\mathrm{N}$ is allocated to photosynthesis (Poorter 
and Evans 1998; Wright et al. 2005). Such a variability of PNUE was for instance detected in seedlings of 14 tropical rainforest species (Coste et al. 2005).

Leaf traits also vary greatly with relative irradiance. Shade and sun leaves differ largely among individuals growing under different levels of irradiance or within the canopy of individual trees. This is the expression of a large irradianceelicited phenotypic plasticity (i.e. the capacity for a given genotype to express several phenotypes under various environmental conditions, Bradshaw 1965). In general, shade leaves are thinner, less dense and display lower LMA than sun leaves (Rijkers et al. 2000; Valladares et al. 2000; Rozendaal et al. 2006). Shade leaves also display higher chlorophyll contents on a mass basis (Poorter et al. 1995; Rijkers et al. 2000) and lower levels of net $\mathrm{CO}_{2}$ assimilation and dark respiration per leaf area ( $A_{\mathrm{sat}} \mathrm{a}$ and $R_{\mathrm{d}} \mathrm{a}$; Givnish 1988; Rijkers et al. 2000). Usually, apparent maximal velocity of RuBP carboxylation $\left(V_{\text {cmax }}\right)$, maximal light driven electron flux $\left(J_{\max }\right)$ and mesophyll conductance to $\mathrm{CO}_{2}$ are smaller in shade leaves (Frak et al. 2001; Piel et al. 2002; Givnish et al. 2004; Montpied et al. 2009) but the ratio $V_{\text {cmax }} / J_{\max }$ remains almost constant across irradiance levels (Niinemets and Tenhunen 1997; Meir et al. 2002). These features are well known and occur in all species tested so far.

Phenotypic plasticity is expected to play a major adaptive role by enhancing carbon assimilation under low irradiance, although it might often be 'passive' (Bradshaw 1965; Rice and Bazzaz 1989; Miner et al. 2005). One of the open questions for a potential adaptive role is whether the magnitude of plastic changes elicited by irradiance differs among populations, species or functional groups of species (Nicotra et al. 1997; Valladares et al. 2006). For instance, pioneer species display a larger plasticity than understory species in some cases (Popma et al. 1992; Strauss-Debenedetti and Bazzaz 1996; Valladares et al. 2000) but not in others (Rozendaal et al. 2006). While irradianceelicited plasticity of leaf traits is a well documented feature, there is still only little information on the potential diversity of this plasticity among a large range of species (Valladares et al. 2000; Bloor and Grubb 2004; Rozendaal et al. 2006).

We examined the inter-specific diversity and the plastic responses to irradiance for leaf traits in saplings from 12 tropical rainforest tree species. Individuals were grown under three levels of relative irradiance in a greenhouse. Fifteen morphological and physiological leaf traits linked to photosynthesis were recorded. Phenotypic plasticity was quantified using the relative-distance plasticity index (RDPI; Valladares et al. 2006). The main objectives of our study were to: (i) record the inter-specific diversity of leaf traits under different irradiance levels; (ii) quantify the irradianceelicited plasticity of leaf traits; and (iii) test whether irradianceelicited plasticity differs between species.

\section{Materials and methods}

All abbreviations and symbols used in the text are listed in Appendix 1 together with the units used.

\section{Plant material}

This study was conducted in a greenhouse at Kourou, French Guiana, South America $\left(5^{\circ} 10^{\prime} \mathrm{N}, 52^{\circ} 40^{\prime} \mathrm{W}\right)$. Measurements were made during 2005 on saplings from 12 tropical rainforest tree species. The species were selected on the basis of widely different values of LMA and encompassed two pioneer, one light-requiring and nine shade-tolerant species (Table 1). All saplings were grown from seed or from very young seedlings collected from March to July 2003 in natural forests around Kourou. They were grown in the greenhouse under different shading nets from in 30-L pots with a $1: 2(\mathrm{v} / \mathrm{v})$ mix of sand and A-horizon soil from a nearby forest in December 2003. In July 2004, all pots received $40 \mathrm{~g}$ slow-release complete fertiliser (Multicote 4, Duclos International, Lunel, France; $17: 17: 17, \mathrm{~N}: \mathrm{P}: \mathrm{K})$. Saplings were treated with a systemic insecticide (Lannate, Du Pont de Nemours, France) and with a contact insecticide (Endosulfan, Thionex, Bayer Crop Science, France) and a fungicide (Ortiva, Syngenta, Belgium). They were irrigated daily with

Table 1. List of the studied rainforest tree species with the abbreviations used in the figures, systematic position and ecological status according to Molino and Sabatier (2001)

Pioneers are strictly gap-dependent, heliophilic species are those that reach the canopy and are seldom found in the understory and shade tolerant are understory species. Shoot height is indicated (mean \pm s.d.) for two relative irradiance levels $\left(5 \%, \mathrm{I}_{5} ; 20 \%, \mathrm{I}_{20}\right)$

\begin{tabular}{|c|c|c|c|c|c|}
\hline \multirow[t]{2}{*}{ Species } & \multirow[t]{2}{*}{ Abbreviation } & \multirow[t]{2}{*}{ Family } & \multirow[t]{2}{*}{ Ecological status } & \multicolumn{2}{|c|}{ Shoot height \pm s.d. $(\mathrm{cm})$} \\
\hline & & & & $\mathrm{I}_{5}$ & $\mathrm{I}_{20}$ \\
\hline Bagassa guianensis J.B. Aublet & $\mathrm{Bg}$ & Moraceae & Pioneer & $154 \pm 19$ & $213 \pm 31$ \\
\hline Cecropia obtusa Trécul. & $\mathrm{Co}$ & Cecropiaceae & Pioneer & $121 \pm 27$ & $203 \pm 37$ \\
\hline Tachigali melinonii (Harms) Barneby & $\mathrm{Tm}$ & Caesalpiniaceae & Heliophilic/non Pioneer & $89 \pm 57$ & $179 \pm 42$ \\
\hline Amanoa guianensis J.B. Aublet & $\mathrm{Ag}$ & Euphorbiaceae & Shade tolerant & $121 \pm 23$ & $189 \pm 48$ \\
\hline Eperua falcata J.B. Aublet & $\mathrm{Ef}$ & Caesalpiniaceae & Shade tolerant & $118 \pm 44$ & $270 \pm 79$ \\
\hline Hymenaea courbaril Linnaeus & $\mathrm{Hc}$ & Caesalpiniaceae & Shade tolerant ${ }^{\mathrm{A}}$ & $142 \pm 27$ & $158 \pm 33$ \\
\hline Pouteria sp. & Ps & Sapotaceae & Shade tolerant & $52 \pm 24$ & $169 \pm 56$ \\
\hline Pradosia cochlearia (Lecomte) Pennington & $\mathrm{Pc}$ & Sapotaceae & Shade tolerant & $84 \pm 28$ & $132 \pm 37$ \\
\hline Protium opacum Swart & Po & Burseraceae & Shade tolerant & $110 \pm 30$ & $215 \pm 23$ \\
\hline Sextonia rubra $(\mathrm{Mez})$ van der Weff & $\mathrm{Sr}$ & Lauraceae & Shade tolerant & $60 \pm 23$ & $170 \pm 49$ \\
\hline Symphonia globulifera Linnaeus $\mathrm{f}$. & $\mathrm{Sg}$ & Clusiaceae & Shade tolerant & $81 \pm 14$ & $132 \pm 40$ \\
\hline Vouacapoua americana J.B. Aublet & Va & Caesalpiniaceae & Shade tolerant & $51 \pm 23$ & $89 \pm 43$ \\
\hline
\end{tabular}

${ }^{\mathrm{A}}$ From the appendix of Poorter (2007). 
drip irrigation in order to maintain volumetric soil humidity between 15 and $32 \%$.

Neutral shading nets were used to create three contiguous $5 \times 12.5$-m large plots corresponding to the three irradiance treatments $\mathrm{I}_{5}, \mathrm{I}_{10}$ and $\mathrm{I}_{20}$ (Table 2). The irradiance treatments were designed to simulate contrasting environments encountered by saplings in natural conditions, including a shade treatment ( $5 \%$ full sun photosynthetic photon flux density, PFD) above the light compensation point of most species (Bloor and Grubb 2003) and two treatments characteristic of small and medium-sized canopy gaps (Baraloto et al. 2005). Full sun was avoided as seedlings from many understory species display poor growth and limited survival under such conditions. Deep shade similar to understory $(<2 \%$ PFD) was avoided for similar reasons, as pioneer species would not survive.

Potted saplings were distributed with the following experimental design: $2 \times 3$ lines of 25 plants per plot, each line containing at least one individual per species at random positions. The distance between individuals was $40 \mathrm{~cm}$ on the line and between lines. Groups of three successive pairs of lines were separated by $1-\mathrm{m}$ wide alleys. Irradiance above the saplings was recorded during two 3-day-long measurement campaigns with 36 inter-calibrated quantum-sensors for photosynthetically active radiation (PAR CBE 80 Solems, Palaiseau, France) compared with an external sensor. Cumulated irradiance recorded by each sensor was used to compute the relative irradiance above saplings (Table 2).

Air temperature and relative humidity were recorded with two HMP45 sensors (Campbell Scientific France, Courtaboeuf,

Table 2. Mean ( \pm s.d.), minimum and maximum transmitted irradiance recorded for 12 species of rainforest tree saplings in the three shaded plots in a greenhouse with three relative irradiance levels $\left(5 \%, I_{5} ; 10 \%, I_{10}\right.$; $\left.20 \%, I_{20}\right)$

Measurements were done during three consecutive days in November 2003 and September 2004 with PAR-quantum sensors. Transmittance expressed as $\%$ of external irradiance

\begin{tabular}{lrrcccc}
\hline $\begin{array}{l}\text { Relative } \\
\text { irradiance }\end{array}$ & \multicolumn{3}{c}{ November 2003 } & \multicolumn{4}{c}{ September 2004 } \\
level & Mean \pm s.d. & Min & Max & Mean \pm s.d. & Min & Max \\
\hline $\mathrm{I}_{5}$ & $4.64 \pm 0.9$ & 3.31 & 6.33 & $4.66 \pm 0.6$ & 3.68 & 6.11 \\
$\mathrm{I}_{10}$ & $8.77 \pm 1.8$ & 6.22 & 13.2 & $9.26 \pm 0.8$ & 8.04 & 11.61 \\
$\mathrm{I}_{20}$ & $18.72 \pm 1.2$ & 17.15 & 21.3 & $20.3 \pm 1.1$ & 18.4 & 22.6 \\
\hline
\end{tabular}

France) located in the middle of plots $\mathrm{I}_{5}$ and $\mathrm{I}_{20}$. They were very close to values recorded in the open, and no difference was recorded among treatments (daily mean temperature: $29.1^{\circ} \mathrm{C}$, $\min / \max$ of $23.9 / 33.3^{\circ} \mathrm{C}$; daily mean relative humidity: $72.6 \%$, $\mathrm{min} / \max$ of $61 / 92 \%$ ). Soil temperature was recorded with three sensors (Campbell Scientific) placed in a single pot of each plot. No treatment related difference was found and mean soil temperatures during days and nights were $24.7^{\circ} \mathrm{C}$ ( $\mathrm{min} / \mathrm{max}$ of $\left.21.4 / 30.6^{\circ} \mathrm{C}\right)$ and $24.4^{\circ} \mathrm{C}\left(\min / \max\right.$ of $\left.21.7 / 28.3^{\circ} \mathrm{C}\right)$, respectively. Five to seven individuals were selected per species and treatment for photosynthesis measurements.

\section{Photosynthetic capacity}

Photosynthetic capacity of leaves was estimated with the photosynthesis model of Farquhar et al. (1980). Two parameters were adjusted to the response curves of $A v$. intercellular mole fraction of $\mathrm{CO}_{2}\left(A-C_{\mathrm{i}}\right.$ curves $)$ :

$V_{\text {cmax }}$, the maximal rate of RuBP carboxylation;

$J_{\max }$, the maximal light driven electron flux.

A detailed description of the model and equations may be found in Le Roux et al. (1999). The primary parameter set was that of Bernacchi et al. (2001) (Table 3). Trials to adjust a complete version of the model including mesophyll conductance to $\mathrm{CO}_{2}$, $g_{\mathrm{m}}$ (Ethier and Livingston 2004) induced a large uncertainty in the estimated values; the procedure was abandoned and $g_{\mathrm{m}}$ was considered to be infinite. The reported values of $V_{\text {cmax }}$ (and to a lesser extent $J_{\max }$ ) should therefore be considered apparent values, with an implicit $g_{\mathrm{m}}$ component. Real values of $V_{\text {cmax }}$ were probably significantly larger.

$A-C_{\mathrm{i}}$ curves were recorded on young, fully expanded leaves selected on top of the main axis with a portable leaf photosynthesis chamber equipped with a $2.5 \mathrm{~cm}^{2}$ Parkinson leaf-clamp chamber (CIRAS-1, PP-System, Hitchin, UK). Leaf temperature was kept between 29 and $32^{\circ} \mathrm{C}$. PFD provided by red LEDs was set to the saturating irradiance of $700 \mu \mathrm{mol} \mathrm{m}^{-2} \mathrm{~s}^{-1}$ for these species. Vapour pressure deficit in the chamber was $1.6 \pm 0.04 \mathrm{kPa}$. Photosynthesis was induced during at least $20 \mathrm{~min}$ at $\sim 200 \mu \mathrm{mol} \mathrm{mol}^{-1} \mathrm{CO}_{2}$ in the chamber. Each $A-C_{\mathrm{i}}$ curve consisted of 13 sequential steps at the following $\mathrm{CO}_{2}$ mole fractions $\left(C_{\mathrm{a}}\right): 50,100,200,300,380,500,600,700$, $900,1100,1300,1500$ and $1700 \mu \mathrm{mol} \mathrm{mol}^{-1}$. Three sets of values of $A$ and $C_{\mathrm{i}}$ were recorded at 10-s intervals after each $\mathrm{CO}_{2}$ step. After running a full $A-C_{\mathrm{i}}$ curve, light was shut down and

Table 3. List of parameters used to adjust the leaf photosynthesis model of Farquhar et al. (1980) to $A-C_{\mathrm{i}}$ curves For details, see Bernacchi et al. (2001)

\begin{tabular}{lccc}
\hline Parameter & Symbol & Value & Unit \\
\hline Quantum yield & $\alpha$ & 0.24 & $\mathrm{~mol} \mathrm{~mol}^{-1}$ photons \\
Rubisco affinity for $\mathrm{CO}_{2}$ at $25^{\circ} \mathrm{C}$ & $K_{\mathrm{c}}$ & 40.49 & $\mathrm{~Pa}$ \\
Activation energy of $K_{\mathrm{c}}$ & $\Delta H_{\mathrm{a}}\left(K_{\mathrm{c}}\right)$ & 79430 & $\mathrm{~J} \mathrm{~mol}^{-1}$ \\
Rubisco affinity for $\mathrm{O}_{2}$ at $25^{\circ} \mathrm{C}$ & $K_{\mathrm{o}}$ & 27840 & $\mathrm{~Pa}$ \\
Activation energy of $K_{\mathrm{o}}$ & $\Delta H_{\mathrm{a}}\left(K_{\mathrm{o}}\right)$ & 36380 & $\mathrm{~J} \mathrm{~mol}^{-1}$ \\
Compensation point for photorespiration at $25^{\circ} \mathrm{C}$ & $\Gamma^{*}$ & 4.275 & $\mathrm{~Pa}$ \\
Activation energy of $\Gamma^{*}$ & $\Delta H_{\mathrm{a}}\left(\Gamma^{*}\right)$ & 37830 & $\mathrm{~J} \mathrm{~mol}^{-1}$ \\
Equivalent $\mathrm{O}_{2}$ concentration in the chloroplast & $\mathrm{O}$ & 21000 & $\mathrm{~Pa}$ \\
\hline
\end{tabular}


respiration recorded after $10 \mathrm{~min}$ stabilisation. $A_{\text {sat }}$ was taken as the value of $A$ recorded at a $C_{\mathrm{a}}$ of $380(379 \pm 3.3) \mu \mathrm{mol} \mathrm{mol}^{-1}$.

\section{Leaf structure and chemistry}

After completion of the $A-C_{\mathrm{i}}$ curves, leaves were harvested and lamina thickness was estimated as the mean of four measurements with a digital micrometer (Digimatic micrometer, Mitutoyo, Japan), care being taken to avoid the main veins. Leaf fresh weight was recorded immediately followed by leaf area with a portable diode-array planimeter Li-Cor 3000A (Li-Cor Inc., Lincoln, Nebraska, USA). Leaves were then dried at $60^{\circ} \mathrm{C}$ for $48 \mathrm{~h}$ and LMA, dry matter content $(\mathrm{LDMC}=1-$ leaf water content on a fresh mass basis, Cornelissen et al. 2003) and leaf density (LMA/thickness) were calculated. A portable chlorophyll meter (SPAD-502, Minolta, Osaka, Japan) was used to estimate chlorophyll content $\left(\mathrm{Chl}, \mu \mathrm{mol} \mathrm{m}^{-2}\right.$ ). A calibration curve relating measurements with the SPAD-502 and chlorophyll content was established for each species (Coste et al. 2010). Dried leaves were ground and mass-based $N\left(N_{\mathrm{m}}\right)$ and C contents $\left(C_{\mathrm{m}}\right)$ were measured with an elemental analyser (ThermoQuest NA 1500 NCS, Carlo Erba, Italy) and used to compute areabased $N_{\mathrm{a}}$.

Intrinsic water use efficiency $\left(\mathrm{WUE}_{\mathrm{i}}\right)$ was estimated from the ratio of light saturated net $\mathrm{CO}_{2}$ assimilation rate on stomatal conductance for water vapour $\left(\mathrm{A} / \mathrm{g}_{\mathrm{s}}\right)$ and from the carbon isotope composition. The ${ }^{13} \mathrm{C}$ isotope composition of bulk leaf biomass, expressed as the difference to a PDBelemnite standard $\left(\delta^{13} \mathrm{C}, \% \circ\right)$ was recorded for the same samples with an isotope ratio mass spectrometer ( $\Delta \mathrm{S}$, Finnigan Mat, Bremen, Germany) at INRA, Nancy, France. Carbon isotope composition of the air was $\delta^{13} C_{a}=-7.85 \%$ (D. Bonal, pers. comm.).

Indirect estimates of photosynthetic nitrogen use efficiency were computed as the ratio between photosynthetic capacity and total $\mathrm{N}$ in the leaves: $A_{\text {sat }}: \mathrm{N}, V_{\text {cmax }}: \mathrm{N}$. The fraction leaf $\mathrm{N}$ allocated to light interception was computed as $\mathrm{Chl}: \mathrm{N}$.

\section{Plasticity index}

A relative distance plasticity index (RDPI; Valladares et al. 2006) was computed for each trait and species as:

$$
\mathrm{RDPI}=\sum\left(\left|x_{i j}-x_{i^{\prime} j^{\prime}}\right| /\left(x_{i j}+x_{i^{\prime} j^{\prime}}\right)\right) / n
$$

with $x_{i j}$, value of the trait for individual $i$ in environment $j$ (three environments in our study); $\left|x_{i j}-x_{i^{\prime} j^{\prime}}\right|$ the absolute difference in trait values computed between all pairs of individuals from two different treatments, and $n$ the total number of pairs.

\section{Statistical analysis}

Three approaches were used to test for differences in plasticity among species: (i) Kendall's coefficient of concordance $(\tau)$ was computed for the traits to compare irradiance treatments; (ii) interactions among species and irradiance levels were tested in the ANOVA analysis; (iii) RDPI was computed for all traits and compared among species and in a principal component analysis (PCA).

All statistical analyses were performed with STATISTICA (Kernel Version 6.0, StatSoft, Tulsa, Oklahoma, USA). Data were $\log _{10^{-}}$or square root-transformed to respect the required data normality and variance homogeneity. Because data were available only for seven species under $\mathrm{I}_{10}$, all analyses presented in the study were applied to the $\mathrm{I}_{5}$ and $\mathrm{I}_{20}$ treatments, except for RDPI that based on the complete dataset. Differences between species, irradiance treatments and their interactions were analysed by a two-way ANOVA. Results of the ANOVA for the three treatments (for seven species) are given in Appendix 2. The final PCA used computed mean values of variables for each species in each treatment. To test whether species ranking of the different irradiance treatments were comparable for all the studied traits, Kendall's $\tau$ was computed from non-transformed data. A one-way ANOVA was used to analyse differences between species for all values of RDPI. All RDPI values were ranked before analysis to avoid the assumptions of normality. All statistical relationships were considered significant at $P<0.05$.

\section{Results}

\section{Interspecific diversity of leaf traits under} a common irradiance

Structural and physiological leaf traits displayed a large interspecific diversity (Fig. 1, Table 4). LMA varied almost three-fold $\left(38-107 \mathrm{~g} \mathrm{~m}^{-2}\right.$ under the highest relative irradiance) and was smallest in the pioneer and shade intolerant species (B. guianensis, C. obtusa and T. melinonii). F-values were highest for structural leaf traits, and particularly for $C_{\mathrm{m}}$ and leaf density $\left(427-489 \mathrm{mg} \mathrm{g}^{-1}\right.$ and $\left.0.18-0.50 \mathrm{~g} \mathrm{~cm}^{-3}\right)$. Leaf nitrogen content $\left(N_{\mathrm{m}}\right)$ varied four-fold $\left(7.3-28.4 \mathrm{mg} \mathrm{g}^{-1}\right)$ but only from 0.59 to $1.40 \mathrm{mg} \mathrm{m}^{-2}$ when expressed on an area basis $\left(N_{\mathrm{a}}\right)$.

Area-based photosynthetic capacity $\left(V_{\operatorname{cmax}}\right.$ a and $J_{\max }$ a) varied almost three-fold (25-73 and 35-120 $\mu \mathrm{mol} \mathrm{m}^{-2} \mathrm{~s}^{-1}$, respectively) and $A_{\text {sat }}$ almost five-fold $\left(2.44-12.0 \mu \mathrm{mol} \mathrm{m}^{-2} \mathrm{~s}^{-1}\right)$. Differences among species were even larger for mass-based photosynthetic capacity, with highest values in C. obtusa and B. guianensis (Fig. 1). Apparent $V_{\text {cmax }}$ and $J_{\max }$ were tightly inter-correlated $\left(r^{2}=0.89 ; P<0.001\right)$ but nevertheless, the ratio $J_{\max } / V_{\text {cmax }}$ varied from 1.19 to 1.75 with a small species effect (Table 4).

$V_{\text {cmax }} / \mathrm{N}$ and $A_{\text {sat }} / \mathrm{N}$, two estimates of PNUE, were highest in the two pioneers, C. obtusa and B. guianensis, and in H. courbaril and smallest in the highly shade-tolerant $V$. americana. $\mathrm{Chl}: \mathrm{N}$ ratio was less variable, with nevertheless very high values in the shade-tolerant $P$. cochlearia.

$\delta^{13} \mathrm{C}$ of bulk leaf matter displayed a large range of values (from -34.5 to $-26.6 \%$ ), i.e. discrimination against ${ }^{13} \mathrm{C}$ varied from 18.8 to $24.7 \%$. This $6 \%$ orange is theoretically equivalent, according to the model of Farquhar and Richards (1984), to a doubling of WUE $\mathrm{E}_{\mathrm{i}}$. The lowest values of $\delta^{13} \mathrm{C}$ (lowest $\mathrm{WUE}_{\mathrm{i}}$ ) were recorded in $V$. americana and the highest in $B$. guianensis. The $A_{\text {sat }}: g_{\mathrm{s}}$ ratio, another estimate of $\mathrm{WUE}_{\mathrm{i}}$, ranged from 34.7 to $64.7 \mu \mathrm{mol} \mathrm{mol}^{-1}$. Due to a large intra-specific variability, the $F$-value observed for $A_{\text {sat }}: g_{\mathrm{s}}$ was very small (Table 4 ; Appendix 2 ) and $\delta^{13} \mathrm{C}$ and $A_{\text {sat }}: g_{\mathrm{s}}$ were only poorly inter-correlated (data not shown).

PCA applied to traits recorded under the highest relative irradiance (Fig. 2) evidenced two first axes explaining $74 \%$ of the observed variability, with $46 \%$ already for axis 1 . The main contributors to axis 1 were $N_{\mathrm{m}}, V_{\text {cmax }} \mathrm{m}$, LMA and $R_{\mathrm{d}} \mathrm{m}$ 

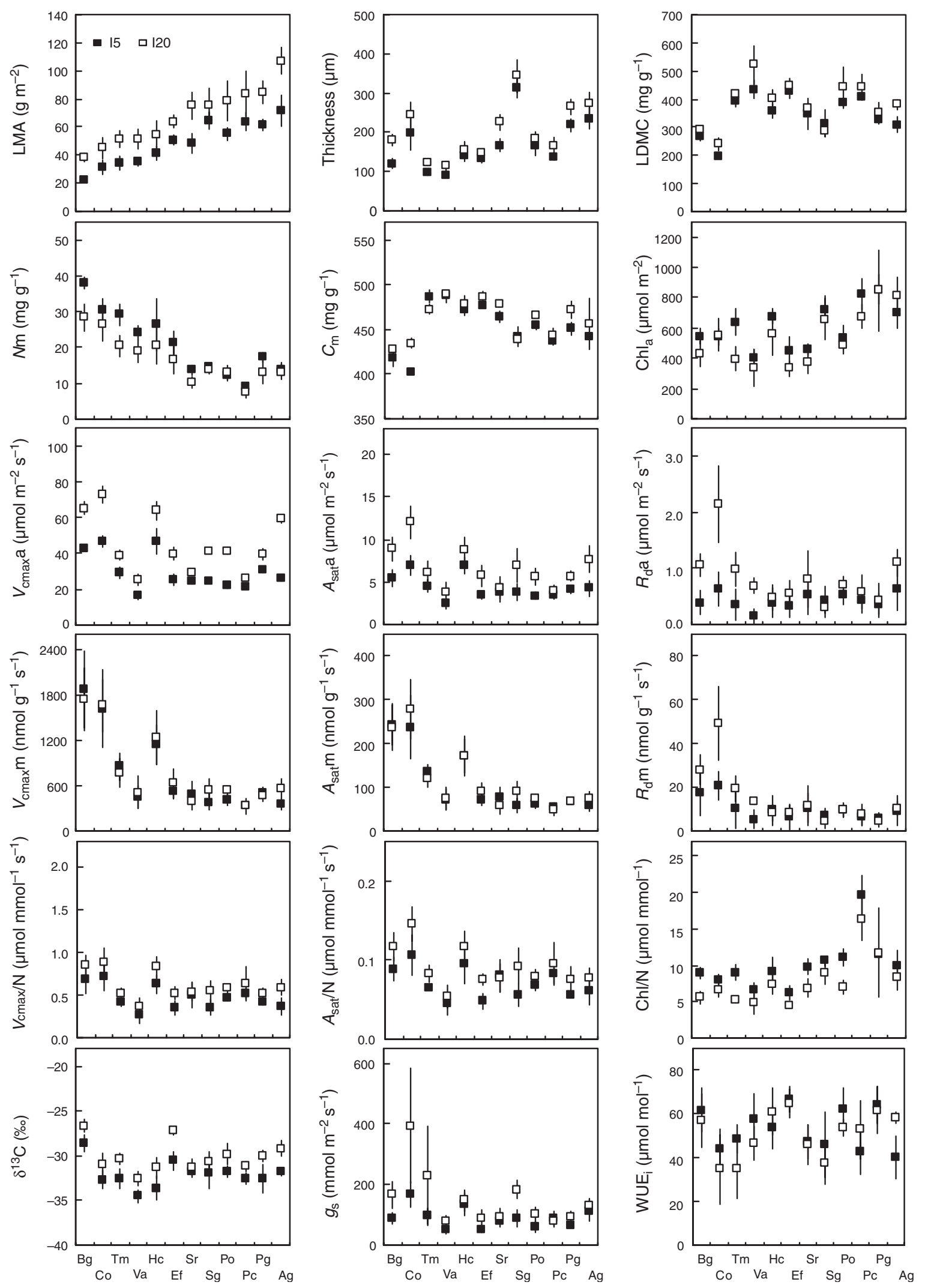

Fig. 1. Values of 18 structural and functional leaf traits in saplings of 12 rainforest tree species (see Table 1 for abbreviations) grown under $5\left(\mathrm{I}_{5}\right)$ and $20 \%\left(\mathrm{I}_{20}\right)$ relative irradiance. Mean values $( \pm 95 \%$ confidence intervals $)$. Species ranked according to increasing leaf mass : area ratio (LMA) under $\mathrm{I}_{20}$. 
Table 4. Results from a two-way ANOVA for the effects of 12 rainforest tree species and two relative irradiance levels $\left(5 \%, I_{5} ; 20 \%, I_{20}\right)$ and their interaction on structural and functional leaf traits

$n=5$ to 7 individuals per species $\times$ irradiance treatments. $F$-values and probability are displayed. With the exception of $\left.\delta^{13} \mathrm{C}_{(\% o}\right), C_{\mathrm{m}}\left(\mathrm{mg} \mathrm{g}^{-1}\right)$ and WUE $\left(\mu \mathrm{mol} \mathrm{mol}^{-1}\right)$, all variables were square root $\left(R_{\mathrm{d}} \mathrm{a}\right.$ and $\left.R_{\mathrm{d}} \mathrm{m}\right)$ or $\log _{10}$-transformed. Mean values $( \pm 95 \%$ confidence interval) are displayed for the two irradiance levels. For each trait, Kendall's coefficient of concordance for mean species values between the two levels of irradiance, are displayed. n.s., not significant, $P>0.05 ; *, P \leq 0.05 ; * *, P \leq 0.01 ; * *, P \leq 0.001$

\begin{tabular}{|c|c|c|c|c|c|c|}
\hline & Species & $\begin{array}{c}\text { Irradiance } \\
F \text {-value }\end{array}$ & $\mathrm{Sp} \times$ Irr. & $\mathrm{I}_{5}$ & $\mathrm{I}_{20}$ & $\overline{\text { Kendall's } \tau}$ \\
\hline \multicolumn{7}{|c|}{ Structural traits } \\
\hline LMA $\left(\mathrm{g} \mathrm{m}^{-2}\right)$ & $53.0 * * *$ & $153^{* * *}$ & $1.30 \mathrm{n} . \mathrm{s}$. & $47.3 \pm 4.1$ & $65.7 \pm 5.4$ & $0.85^{* * *}$ \\
\hline Thickness $(\mu \mathrm{m})$ & $71.1 * * *$ & $88.6^{* * *}$ & 1.51 n.s. & $166 \pm 16$ & $203 \pm 17$ & $0.88 * * *$ \\
\hline Density $\left(\mathrm{g} \mathrm{cm}^{-3}\right)$ & $96.1 * * *$ & $52.1 * * *$ & 0.63 n.s. & $0.30 \pm 0.02$ & $0.34 \pm 0.03$ & $0.97 * * *$ \\
\hline $\operatorname{LDMC}\left(\mathrm{mg} \mathrm{g}^{-1}\right)$ & $58.5^{* * *}$ & $27.8 * * *$ & 1.62 n.s. & $343 \pm 19$ & $376 \pm 22$ & $0.82 * * *$ \\
\hline$C_{\mathrm{m}}\left(\mathrm{mg} \mathrm{g}^{-1}\right)$ & $116^{* * *}$ & $36.9 * * *$ & $7.46^{* * *}$ & $451 \pm 6.8$ & $459 \pm 5.6$ & $0.79 * * *$ \\
\hline$N_{\mathrm{a}}\left(\mathrm{mg} \mathrm{m}^{-2}\right)$ & $11.3^{* * *}$ & $14.5 * * *$ & 1.30 n.s. & $0.90 \pm 0.05$ & $1.03 \pm 0.07$ & $0.52^{* *}$ \\
\hline$N_{\mathrm{m}}\left(\mathrm{mg} \mathrm{g}^{-1}\right)$ & $53.6^{* * *}$ & $39.4 * * *$ & 1.09 n.s. & $21.6 \pm 2.3$ & $17.6 \pm 1.8$ & $0.88^{* * *}$ \\
\hline $\mathrm{Chl}_{\mathrm{a}}\left(\mu \mathrm{mol} \mathrm{m}{ }^{-2}\right)$ & $17.5^{* * *}$ & $18.6^{* * *}$ & 1.47 n.s. & $602 \pm 39$ & $537 \pm 52$ & $0.76^{* * *}$ \\
\hline $\mathrm{Chl}_{\mathrm{m}}\left(\mu \mathrm{mol} \mathrm{g}{ }^{-1}\right)$ & $14.7 * * *$ & $128 * * *$ & 1.75 n.s. & $14.2 \pm 1.3$ & $8.70 \pm 0.9$ & $0.70^{* *}$ \\
\hline \multicolumn{7}{|c|}{ Physiological traits } \\
\hline$V_{\text {cmax }} \mathrm{a}\left(\mu \mathrm{mol} \mathrm{m} \mathrm{m}^{-2} \mathrm{~s}^{-1}\right)$ & $15.6 * * *$ & $63.8 * * *$ & 1.02 n.s. & $30.4 \pm 3.2$ & $46.7 \pm 4.9$ & $0.61 * *$ \\
\hline$J_{\max } \mathrm{a}\left(\mu \mathrm{mol} \mathrm{m} \mathrm{m}^{-2} \mathrm{~s}^{-1}\right)$ & $18.4 * * *$ & $69.2 * * *$ & $2.48 * *$ & $43.9 \pm 3.5$ & $69.3 \pm 8.2$ & $0.67 * *$ \\
\hline$R_{\mathrm{d}} \mathrm{a}\left(\mu \mathrm{mol} \mathrm{m} \mathrm{m}^{-2} \mathrm{~s}^{-1}\right)$ & $5.25^{* * *}$ & $34.4 * * *$ & $2.76^{* *}$ & $0.43 \pm 0.07$ & $0.87 \pm 0.16$ & 0.30 n.s. \\
\hline$V_{\text {cmax }} \mathrm{m}\left(\mathrm{nmol} \mathrm{g}^{-1} \mathrm{~s}^{-1}\right)$ & $38.4 * * *$ & 1.57 n.s. & 1.02 n.s. & $797 \pm 154$ & $839 \pm 142$ & $0.58 * *$ \\
\hline$J_{\max } \mathrm{m}\left(\mathrm{nmol} \mathrm{g}^{-1} \mathrm{~s}^{-1}\right)$ & $49.3^{* * *}$ & 0.47 n.s. & $2.09^{*}$ & $1122 \pm 176$ & $1276 \pm 246$ & $0.55^{*}$ \\
\hline$R_{\mathrm{d}} \mathrm{m}\left(\mathrm{nmol} \mathrm{g}{ }^{-1} \mathrm{~s}^{-1}\right)$ & $9.16^{* * *}$ & $8.81 * *$ & 1.88 n.s. & $10.3 \pm 2.1$ & $16.1 \pm 3.9$ & $0.52 *$ \\
\hline$J_{\max }: V_{\mathrm{cmax}}$ & $2.59 * *$ & 2.18 n.s. & $3.11 * *$ & $1.53 \pm 0.1$ & $1.48 \pm 0.1$ & $<0.001$ n.s. \\
\hline$A_{\mathrm{sat}} \mathrm{a}\left(\mu \mathrm{mol} \mathrm{m} \mathrm{m}^{-2} \mathrm{~s}^{-1}\right)$ & $18.3 * * *$ & $76.9 * * *$ & 1.24 n.s. & $4.48 \pm 0.4$ & $6.87 \pm 0.7$ & $0.73 * * *$ \\
\hline$A_{\mathrm{sat}} \mathrm{m}\left(\mathrm{nmol} \mathrm{g}^{-1} \mathrm{~s}^{-1}\right)$ & $42.8^{* * *}$ & 0.83 n.s. & 1.29 n.s. & $116 \pm 20$ & $124 \pm 22$ & $0.55^{*}$ \\
\hline$V_{\text {cmax }}: \mathrm{N}\left(\mu \mathrm{mol} \mathrm{mmol}^{-1} \mathrm{~s}^{-1}\right)$ & $15.3^{* * *}$ & $37.2 * * *$ & 0.56 n.s. & $0.48 \pm 0.05$ & $0.63 \pm 0.05$ & $0.67 * *$ \\
\hline$J_{\max }: \mathrm{N}\left(\mu \mathrm{mol} \mathrm{mmol}^{-1} \mathrm{~s}^{-1}\right)$ & $16.7 * * *$ & $38.3 * * *$ & $2.40^{* *}$ & $0.70 \pm 0.05$ & $0.93 \pm 0.09$ & $0.52 *$ \\
\hline$A_{\text {sat }}: \mathrm{N}\left(\mu \mathrm{mol} \mathrm{mmol}^{-1} \mathrm{~s}^{-1}\right)$ & $13.0^{* * *}$ & $35.0 * * *$ & 0.9 n.s. & $0.07 \pm 0.01$ & $0.09 \pm 0.01$ & $0.76 * * *$ \\
\hline $\mathrm{Chl}: \mathrm{N}\left(\mu \mathrm{mol} \mathrm{mmol}{ }^{-1}\right)$ & $24.5^{* * *}$ & $64.3 * * *$ & 1.24 n.s. & $9.98 \pm 0.9$ & $7.69 \pm 0.9$ & $0.79 * * *$ \\
\hline$\delta^{13} \mathrm{C}(\%)$ & $21.1 * * *$ & $89.0 * * *$ & 1.00 n.s. & $-32 \pm 0.5$ & $-30 \pm 0.5$ & $0.64 * *$ \\
\hline$g_{\mathrm{s}}\left(\mathrm{mmol} \mathrm{m} \mathrm{s}^{-2} \mathrm{~s}^{-1}\right)$ & $15.6^{* * *}$ & $55.4 * * *$ & $2.05^{*}$ & $91.8 \pm 11$ & $150 \pm 29$ & $0.55^{* *}$ \\
\hline $\mathrm{WUE}_{\mathrm{i}}\left(\mu \mathrm{mol} \mathrm{mol}{ }^{-1}\right)$ & $5.81 * * *$ & 1.07 n.s. & 1.62 n.s. & $53.1 \pm 3.4$ & $50.9 \pm 3.8$ & 0.39 n.s. \\
\hline
\end{tabular}

(coordinates $0.95,0.95,-0.85$ and 0.83 , respectively), and to axis 2, leaf thickness and LDMC (coordinates -0.83 and 0.81 , respectively). $V_{\text {cmax }}: \mathrm{N}$ and $\mathrm{Chl}: \mathrm{N}$ were independent from each other. The distribution of species on the factor plane (axes 1 and 2) yielded a clear ranking, with the two pioneers $C$. obtusa and $B$. guianensis displaying the highest values on axis 1 . Among the remaining, $T$. melinonii and $H$. courbaril exhibited highest and $P$. cochlearia lowest values on axis 1 (Fig. 2). V. americana was at the positive extreme of axis 2 , while several species were at the opposite. The same conclusions apply to the data obtained under low irradiance: the trait scores on PCA-axis 1 and 2 were tightly inter-correlated between the two treatments (axis 1: $r^{2}=0.99$, $P<0.001$; axis 2: $\left.r^{2}=097, P<0.001\right)$.

\section{Irradiance-elicited plasticity of leaf traits}

As expected, we found a large irradiance-elicited plasticity for all traits with the notable exception of mass-based photosynthetic capacity $\left(A_{\text {sat }} \mathrm{m}, \quad V_{\text {cmax }} \mathrm{m}\right.$ and $\left.J_{\text {max }} \mathrm{m}\right)$ and of $A_{\text {sat }}: g_{\mathrm{s}}$ (Table 4). Leaves were thicker, denser and had a larger LMA under high irradiance $\left(\mathrm{I}_{20}\right)$ (Fig. 1, Table 4). They also displayed larger total leaf nitrogen combined with smaller chlorophyll content (whether on a mass or on an area-basis). $\delta^{13} \mathrm{C}$ increased from $-32 \pm 0.5$ to $-30 \pm 0.5 \%$; i.e. a $25 \%$ increase in modelled WUE $\mathrm{E}_{\mathrm{i}}$ between $\mathrm{I}_{5}$ and $\mathrm{I}_{20}$. This contradicts to some extent the lack of effect on $A_{\text {sat }}: g_{\mathrm{s}}$. Parallel to LMA, area-based photosynthetic capacity significantly increased $(P<0.0001)$ with irradiance, as did PNUE. The ratio $\mathrm{Chl}: \mathrm{N}$ decreased with increased irradiance (Table 4, Fig. 1).

\section{Inter-specific diversity of plasticity}

A large irradiance-elicited plasticity was recorded in all tested species. Interactions between species and irradiance effects remained barely significant, and the Kendall's $\tau$ comparing the ranking of species between the two treatments was very high $\left(r^{2}>0.90\right.$, Table 4$)$. A significant species $\times$ irradiance interaction was detected for $C_{\mathrm{m}}, J_{\max }$ a, $J_{\max } \mathrm{m}, J_{\max }: \mathrm{N}, R_{\mathrm{d}} \mathrm{a}$ and $g_{\mathrm{s}}$ but the $F$-values were much smaller for the interaction than for the main effects. Except for $R_{\mathrm{d}}$ a and $A_{\mathrm{sat}}: g_{\mathrm{s}}$, the ranking of species between $\mathrm{I}_{5}$ and $\mathrm{I}_{20}$ was not affected by the interaction (Table 4 ). $R_{\mathrm{d}}$ a tended to increase with irradiance but it decreased for $S$. globulifera. $A_{\text {sat }}: g_{\mathrm{s}}$ increased with irradiance in $P$. cochlearia, $P$. opacum and $H$. courbaril while it decreased in the other species (Fig. 1).

RDPI differed among traits and species (Fig. 3; $P<0.001$ ). The highest values were found for $R_{\mathrm{d}} \mathrm{a}, R_{\mathrm{d}} \mathrm{m}, V_{\text {cmax }} \mathrm{a}$ and $g_{\mathrm{s}}$ and the 

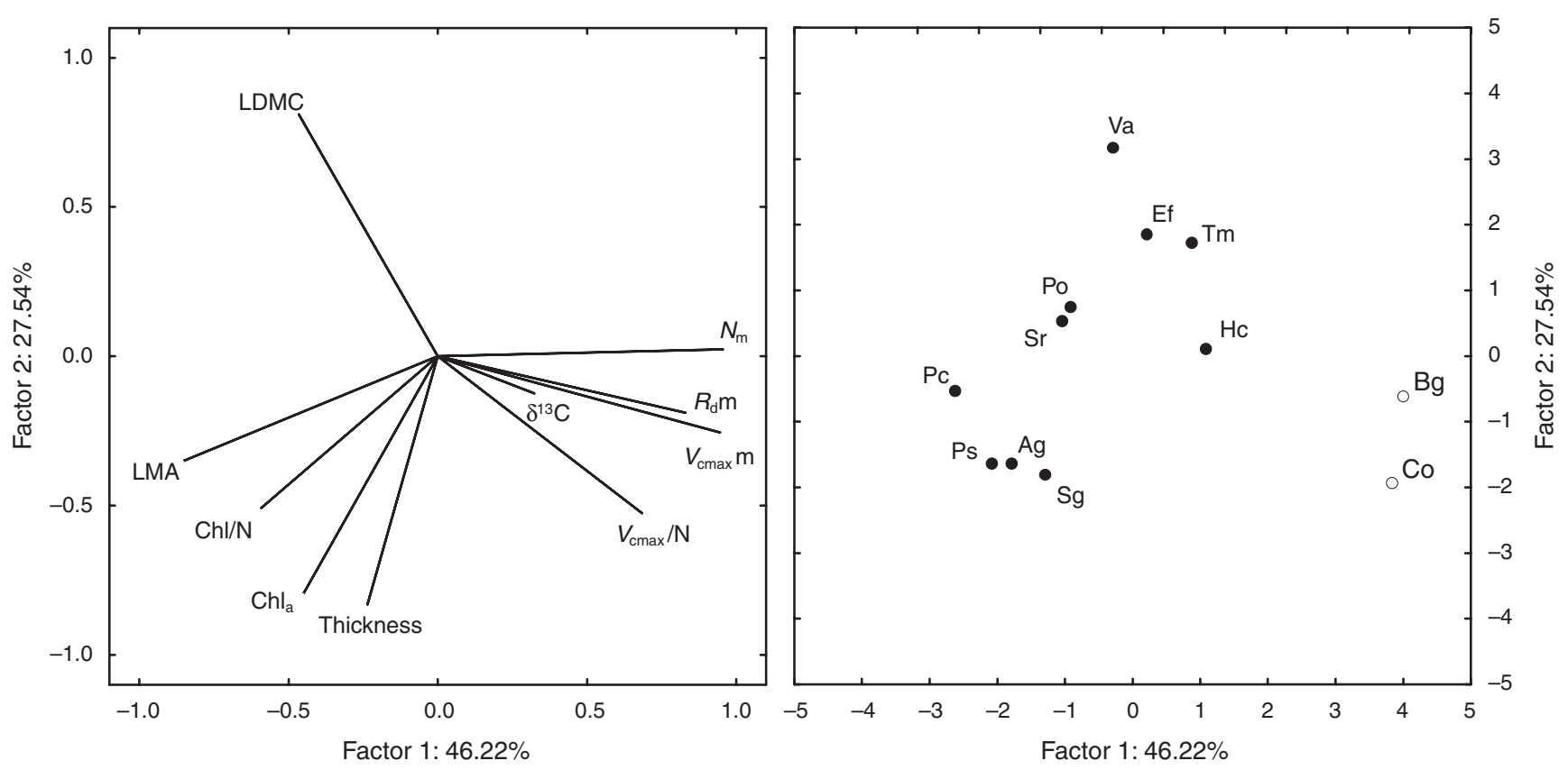

Fig. 2. Principal component analysis of the 12 rainforest tree species ordinated according to the mean value of 10 traits recorded under the highest relative irradiance level $\left(20 \%\right.$ relative irradiance, $\left.\mathrm{I}_{20}\right)$. The leaf traits were: leaf mass : area ratio, LMA; leaf thickness; leaf dry mater content, LDMC; mass-based maximum rate of carboxylation, $V_{\text {cmax }} \mathrm{m}$; mass-based dark respiration, $R_{\mathrm{d}} \mathrm{m}$; leaf carbon isotope composition, $\delta^{13} \mathrm{C}$; mass-based total nitrogen content, $N_{\mathrm{m}}$; total chlorophyll content per unit leaf area, $\mathrm{Chl}_{\mathrm{a}} ; V_{\mathrm{cmax}}: N$ and $\mathrm{Chl}: N$. Projections of the traits and of the species on the factor-planes $(1 \times 2)$ are shown. The two pioneer species are indicated by white dots. Abbreviations indicate species (Table 1).

smallest for $\delta^{13} \mathrm{C}, C_{\mathrm{m}}, \mathrm{LDMC}$, density and thickness. The largest inter-specific diversity was found for $C_{\mathrm{m}}(F=24.7)$ consistently with the above cited interaction effect. Nevertheless, the two pioneers $C$. obtusa and B. guianensis did not differ from the shade tolerant species, except for $C_{\mathrm{m}}$ in C. obtusa (Fig. 3). PCA was applied to RDPI for LMA, leaf thickness, LDMC, $N_{\mathrm{m}}, C_{\mathrm{m}}, \mathrm{Chl}_{\mathrm{a}}$ $A_{\text {sat }} \mathrm{a}, R_{\mathrm{d}} \mathrm{a}, \delta^{13} \mathrm{C}, A_{\text {sat }}: \mathrm{N}$ and $\mathrm{Chl}: \mathrm{N}$ (Fig. 4 ). The two first axes explained $57 \%$ of the observed variability. The main contributors to the first principal axis were RDPI of LDMC, LMA and $V_{\text {cmax }} \mathrm{m}$ (coordinates $0.87,0.78$ and 0.71 , respectively). The main contributors to the second axis were RDPI of $V_{\text {cmax }}: \mathrm{N}$ and $\mathrm{Chl}: \mathrm{N}$ (coordinates -0.83 and 0.80 , respectively). S. globulifera had the highest RDPI for $A_{\text {sat }}: \mathrm{N}$ and the smallest for $\mathrm{Chl}: \mathrm{N}$, which was exactly the opposite of P. opacum (Fig. 4). Nevertheless, the variations in RDPI did not result in a clear pattern of correlations among variables or among species.

\section{Discussion}

\section{Inter-specific diversity of leaf traits}

This set of 12 tropical rainforest tree species displayed a large range of values for leaf mass: area ratio, LMA $\left(40-100 \mathrm{~g} \mathrm{~m}^{-2}\right.$ under the highest relative irradiance). Such values reflect a large diversity although they probably are smaller than the ones reached on adult trees (Poorter et al. 2009). It showed also a large interspecific diversity of structural and physiological leaf traits. Leaf thickness, leaf density and leaf dry matter content varied more than three-fold. Thickness and dry matter content were negatively correlated. Large differences were also observed in nitrogen content on a mass basis $\left(N_{\mathrm{m}}\right)$, which was tightly and negatively correlated with LMA as expected from earlier studies (Poorter and Evans 1998). These differences in leaf structure and chemical composition were paralleled by a large variability in area and mass-based photosynthetic capacity, expressed either as the light-saturated net $\mathrm{CO}_{2}$ assimilation rate $\left(A_{\text {sat }}\right)$, or as the maximal carboxylation rate by Rubisco $\left(V_{\text {cmax }}\right)$. This large diversity in $N_{\mathrm{m}}$ results in low levels of mass-based $V_{\text {cmax }}$ in the case of high LMA species.

A PCA analysing the correlations between leaf traits showed that almost $50 \%$ of the observed inter-specific variability was captured by the main axis which sets LMA against mass-based photosynthetic capacity and $N_{\mathrm{m}}$. This was consistent with the "leaf economic spectrum' proposed by Wright et al. (2004), which runs from species with high $N_{\mathrm{m}}$, high photosynthetic capacity and $R_{\mathrm{d}}$, short leaf-life-span and small LMA (quick returns on investments of nutrients and dry mass) to species with long leaf life-span, expensive leaf (large LMA), low $N_{\mathrm{m}}$, respiration and rates of photosynthesis (slower potential rate of return).

Nevertheless, despite the tight correlation observed between mass-based photosynthetic capacity and $N_{\mathrm{m}}$, PNUE, expressed as $V_{\text {cmax }}: \mathrm{N}$ or $A_{\text {sat }}: \mathrm{N}$, varied widely among species and contributed to the differences in photosynthesis. Moreover, PNUE was negatively correlated with LMA and this confirms that in high LMA leaves relative $\mathrm{N}$ allocation to Rubisco and light-driven electron transport is smaller (Poorter and Evans 1998). This confirms also our earlier observations with a slightly different set of species (Coste et al. 2005). Such differences of relative 

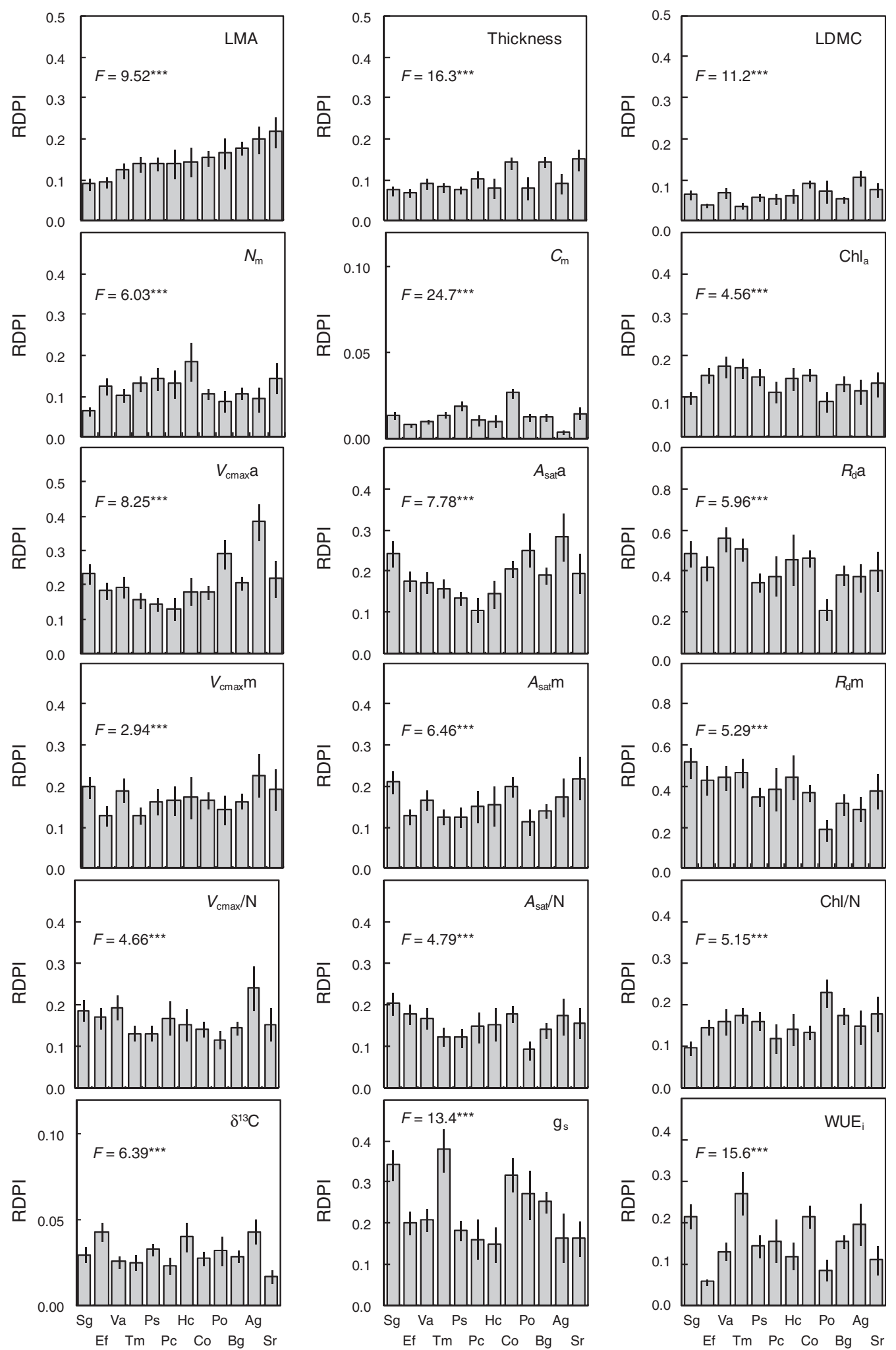

Fig. 3. Mean value ( $\pm 95 \%$ confidence intervals) of Relative Distance Plasticity Index (RDPI) for 18 structural and functional leaf traits (see Table 1 for abbreviations). This index ranging from 0 (no plasticity) to 1 (maximal plasticity) was computed per trait and species. Differences between species were tested by a one way ANOVA ( $F$-values are displayed). Species within were ranked according to increasing mean RDPI values of leaf mass : area ratio (LMA). Significance levels: n.s., not significant, $P>0.05$; $^{*}, P \leq 0.05 ; * *, P \leq 0.01{ }^{* * *}, P \leq 0.001$. Note that the $y$-axes are different among traits. 

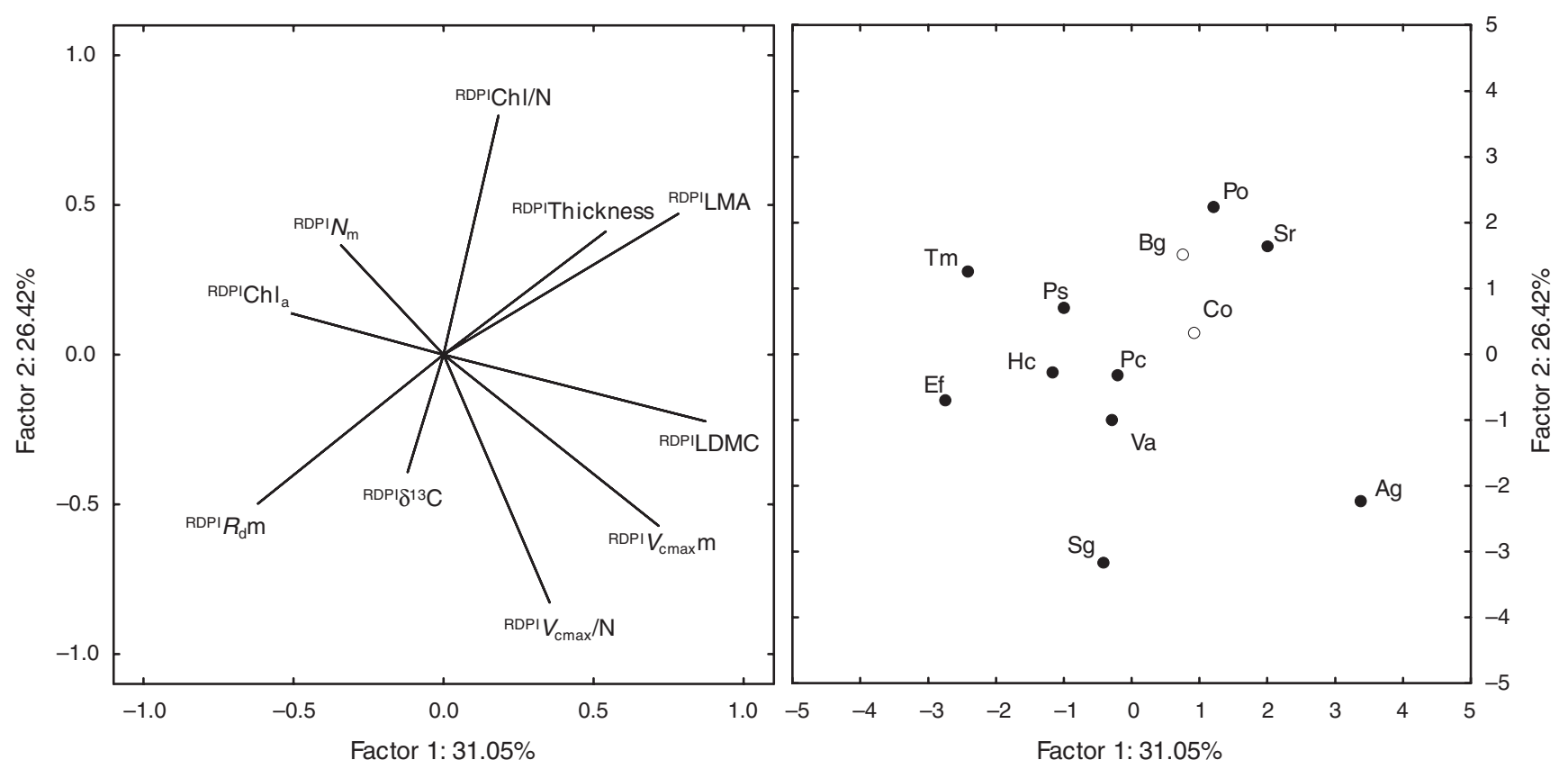

Fig. 4. Principal component analysis of the 12 rainforest tree species ordinated according to the phenotypic plasticity for 10 traits: relative distance plasticity index (RDPI) of leaf mass : area ratio (LMA), leaf thickness, leaf dry matter content (LDMC), $V_{\mathrm{cmax}} \mathrm{m}, R_{\mathrm{d}} \mathrm{m}$, leaf carbon isotope composition $\delta^{13} \mathrm{C}, N_{\mathrm{m}}, \mathrm{Chl} \mathrm{a}_{\mathrm{a}}$, $V_{\text {cmax }}: \mathrm{N}$ and $\mathrm{Chl}: \mathrm{N}$ ratio. Projection of the variables of the species on the factor planes $(1 \times 2)$ are shown. See Table 1 for abbreviations. Pioneer species are indicated by white dots.

allocation of leaf $\mathrm{N}$ to photosynthetic processes may be due to a larger investment of $\mathrm{N}$ into cell wall components, defence compounds and other non-photosynthetic processes in high LMA leaves.

The presented values of $V_{\text {cmax }}$ were computed under the assumption of an infinite mesophyll conductance to $\mathrm{CO}_{2}\left(g_{\mathrm{m}}\right)$, while there is now a large body of evidence demonstrating that $g_{\mathrm{m}}$ is finite and induces a significant drop of $\mathrm{CO}_{2}$ concentration from the intercellular air spaces to the chloroplast stroma (Evans and von Caemmerer 1996; Warren and Adams 2006; Evans et al. 2009). We attempted to estimate the values of $g_{\mathrm{m}}$ from our $A-C_{\mathrm{i}}$ curves as suggested by Ethier and Livingston (2004), but due to a large residual variability, we were unable to obtain reliable fits. The degree of inter-specific variability of $g_{m}$ in the tested species remains an open question.

The large inter-specific diversity recorded in the discrimination against ${ }^{13} \mathrm{C}$ and in $\mathrm{WUE}_{\mathrm{i}}$ (the ratio net assimilation rate/stomatal conductance) is coherent with the one described by Bonal et al. (2007) for saplings of tropical rainforest species grown under moderate shade. Moreover, $\delta^{13} \mathrm{C}$ recorded in juveniles and adults from the same species were intercorrelated, which confirms that the observed differences are not specific to a given ontogenetic stage (Bonal et al. 2007). The large variability of the recorded values of $\mathrm{WUE}_{\mathrm{i}}$ is due to the measurement procedure and is a common observation in such experiments; as a consequence we were unable to assess to what extent $\delta^{13} \mathrm{C}$ described time-integrated $\mathrm{WUE}_{\mathrm{i}}$ and was not affected by mesophyll conductance of by post-photosynthetic discrimination of ${ }^{13} \mathrm{C}$ (Cernusak et al. 2007). That fact that $\delta^{13} \mathrm{C}$ was not correlated with any photosynthetic trait means that $\mathrm{WUE}_{\mathrm{i}}$ was probably controlled by stomatal conductance rather than by photosynthetic capacity. The importance of stomata in controlling the diversity of $\mathrm{WUE}_{\mathrm{i}}$ was recently evidenced for oak genotypes by Roussel et al. (2009).

The two pioneer species, B. guianensis and C. obtusa, were located at one end of the factor 1 axis, which reflects high photosynthetic capacity, large respiration, high $N_{\mathrm{m}}$ and PNUE and low LMA (i.e. quick acquisition of resources) and differentiated clearly from all other species. The 10 remaining species were distributed along axis 1 but also along axis 2 opposing LDMC and thickness. In this group of species photosynthetic capacity, LMA and $N_{\mathrm{m}}$ were less diverse, while leaf structure largely differentiated them; in general, there was a trade-off between thickness and density.

These inter-specific differences were very stable among irradiance treatments, as illustrated by the very tight correlation between the coordinates of the different traits and species in the PCAs obtained with the two levels of irradiance. This stability opens the question of potential differences in irradiance-elicited plasticity among our species (discussed below).

\section{Irradiance-elicited plasticity of leaf traits}

The large plasticity, elicited by rather moderate changes in irradiance and recorded for almost all leaf traits, followed the expected pattern (Rijkers et al. 2000; Valladares et al. 2000; Rozendaal et al. 2006): leaves of saplings grown under the lowest irradiance were thinner, less dense and displayed a lower LMA, lower $\mathrm{C}$ content than under higher irradiance. Surprisingly, they 
also displayed a higher $\mathrm{N}$ content. This contradicts to some extent earlier results showing a stability of $N_{\mathrm{m}}$ with relative irradiance (Rozendaal et al. 2006; Montpied et al. 2009), but fits with observations of Roggy et al. (2005) where $N_{\mathrm{m}}$ increased similarly with decreasing relative irradiance within the canopy of Dicorynia guianensis Amshoff trees in a tropical rainforest. Such a pattern may be explained by: (i) larger $\mathrm{N}$ requirements for the investment into light-harvesting structure under low relative irradiance; (ii) a dilution of leaf $\mathrm{N}$ by the large amount of photosynthates (mainly starch) accumulated in leaves under high irradiance; and (iii) a small N-deficiency due to the fact that growth was much faster under high irradiance and possibly mobilised a large fraction of the $\mathrm{N}$ provided in the pots. Leaf chlorophyll content was larger under low irradiance, whether expressed on a mass or area basis, and in spite of the net decrease of LMA. This observation contrasts with those of Rozendaal et al. (2006) and Poorter et al. (1995) where the negative co-variation of LMA and $\mathrm{Chl}_{\mathrm{m}}$ with irradiance resulted in similar values of $\mathrm{Chl}_{\mathrm{a}}$ among sun and shade leaves and hence, similar light harvesting capacities per leaf area.

Photosynthetic capacity displayed the expected irradianceelicited plasticity with large differences of area-based and a stability of mass-based values with increasing irradiance. This highlights LMA as an important driver for the plasticity of photosynthetic capacity under changing irradiance (Montpied et al. 2009). In addition, larger PNUE associated to smaller $N_{\mathrm{m}}$ and $\mathrm{Chl}: \mathrm{N}$ were observed under high irradiance: differential allocation of $\mathrm{N}$ to photosynthetic structure did at least partly contribute to the plastic response of the leaf photosynthesis. A likely hypothesis is that under low irradiance, there is a relative accumulation of non-activated Rubisco that possibly plays a role as nitrogen storage (Warren et al. 2003); under high irradiance in contrast, there are larger pools of highlyactivated Rubisco. Another hypothesis is that under low irradiance, mesophyll conductance to $\mathrm{CO}_{2}\left(g_{\mathrm{m}}\right)$ is smaller (Piel et al. 2002; Montpied et al. 2009), which results in a larger underestimation of $V_{\text {cmax }}$ under high than irradiance, and impacts the comparison of PNUE values. It needs be mentioned that maximal PNUE (i.e. $A_{\text {sat }}: \mathrm{N}$ ) was also larger under high irradiance.

These results also confirm findings synthesised by Lusk et al. (2008): all traits related to carbon gain displayed parallel plasticity and evolutionary variation (concept of 'co-gradient variation'): leaves in shade phenotypes displayed lower photosynthetic capacity and PNUE as did shade tolerant when compared with pioneer species. By contrast, LMA was in general larger in shade tolerant than in pioneer and heliophilic species, which corresponds to a 'counter gradient variation' like the one described by Lusk et al. (2008) in evergreen trees.

\section{Inter-specific diversity of irradiance-elicited plasticity}

Little evidence was found for the occurrence of an inter-specific variability of irradiance-elicited plasticity among species. This statement bases on three observations: (i) there were only very minor interactions among species and irradiance effects for all traits (usually below the significance threshold, and always very small compared with the main effects); (ii) for a given trait, the species ranking was largely maintained in the different irradiance levels; and (iii) direct computation of RDPI revealed some variability but no consistent pattern among traits and species when analysed with a PCA.

From the series of plasticity indexes analysed by Valladares et al. (2006), RDPI seemed the most useful as it is not based on any implicit assumption about the linearity of reaction norms, and allows for some statistical analyses. Until now, RDPI was seldomly used, which makes any cross-comparison with our data difficult, although similar indexes were used in earlier papers like the relative variation among mean traits values under different levels of irradiance. The use of plasticity indexes requires some care and comparisons among traits can be very tricky. Indeed, traits with a small range of variation lead to small values of RDPI, while such small variation may still represent a large phenotypic effect. This was in particular the case for $C_{\mathrm{m}}$ and $\delta^{13} \mathrm{C}$. In the latter case, the use of relative plasticity indexes needs great care: the $\delta^{13} \mathrm{C}$ is a relative scale with an arbitrary origin (like temperature, for instance) and changing the origin changes the value of the estimated plasticity index, but fortunately, not the variability among species.

A first analysis of RDPI revealed the occurrence of some variability among species for a few traits. To obtain a more synthetic view of the overall plasticity of the tested species, we used a PCA with the whole RDPI dataset. Such an approach was also used by Bloor and Grubb (2004) with a slightly different index. This was more informative compared with the computation of a mean value of plasticity per species (Valladares et al. 2000). We detected no visible difference or trade-off in plasticity between structural (LMA, LDMC, $N_{\mathrm{m}}$ ) and physiological $\left(V_{\text {cmax }}, A_{\text {sat }}, \mathrm{WUE}_{\mathrm{i}}\right)$ traits. Similarly, we detected no meaningful grouping of traits for their RDPI value and found no evidence for a difference in plasticity between the two fastgrowing pioneers and the other species.

The small inter-specific variability of RDPI observed may therefore reflect a statistical variability rather than an ecologically significant trend. This is apparently in contradiction with recent publications on plasticity in trees that claim the occurrence of some diversity in plasticity among species (Bloor and Grubb 2004) but not with others that found some differences among traits, but not among species, and moreover, not among functional groups of species (Rozendaal et al. 2006; Markesteijn et al. 2007). There are, nevertheless, several points that need be considered for the debate on variable plasticity among species and hence on the adaptive significance of plasticity:

(i) the computation of many plasticity indexes is biased and it is difficult to compare the degree of plasticity among traits; small variations in some traits may have large consequences for the physiology of a tree; there is a need for a development of quantitative and comparative approaches to plasticity;

(ii) in the case of growth in shade, survival of saplings does not depend on a single trait or on carbon assimilation alone. It probably depends on the ability to maintain a positive carbon balance at the level of the individual (Niinemets 2006; Valladares and Niinemets 2008), which in turn depends on the balance between respiring support structures and assimilating (leaf) surfaces, leaf life span; i.e. on a large array of complementary traits. We might 
hypothesise that the plasticity in sapling structure, for instance, in the ratio leaf area: sapling biomass (LAR) or in leaf-life-span might have a larger impact than that on traits solely controlling net $\mathrm{CO}_{2}$ assimilation rate;

(iii) our observations were made under a relatively small gradient of irradiance (relative irradiance varied between 5 and $30 \%$, which does not cover the full range of irradiance seedlings may encounter in forests $(1-100 \%$ relative irradiance). There are few datasets covering the full range of irradiance and we have little knowledge about the form of the reaction norm over the whole range of irradiance. Nevertheless, the reaction norm is not linear, it slope is steeper in the lowest range. This might be of importance for differences in plasticity among species;

(iv) a last hypothesis would be that constitutive values of traits like LAR, leaf-life-span and others contributing to survival under deep shade have a much large impact on fitness and that irradiance-elicited plasticity is similar among species and not related to their fitness in situ. This rather extreme hypothesis cannot be discarded when examining the present dataset.

\section{Conclusion}

This study demonstrated the occurrence of large inter-specific diversity and irradiance-elicited plasticity in leaves of saplings from 12 tropical rainforest tree species. Pioneer species displayed larger photosynthesis associated to a larger PNUE and a smaller LMA compared with shade tolerant ones. The plastic response included a large decrease of LMA, photosynthesis and PNUE with decreasing relative irradiance. Contrary to expectations, there was no difference in plasticity of these leaf traits among species: pioneers and shade tolerant species displayed similar levels of plasticity. Shade tolerance is probably related to the cumulated carbon balance of leaves and support structures and is impact also by organ turn-over. Investigating cumulated carbon gain of shade and sun leaves and establishing a cost-benefit analysis in shade tolerant $v$. pioneer species are areas for future research. Finally, it has to be stated that our conclusions apply to irradiance-elicited plasticity in young saplings. Due to potential changes of plasticity with ontogenesis, this conclusion would require a confirmation at later stages of development.

\section{Acknowledgements}

S. Coste was supported by a PhD grant from the French Ministry for Higher Education and Research and by a grant for technical cooperation in overseas regions of France. The authors are indebted to Pascal Imbert, Saintano Dufort, Marcel Blaise, Jean-Louis De Kerpeztron and Henry Grootfaam (UMR Ecofog, Kourou) for their help throughout the experiment and to Claude Brechet and Jacqueline Marchand (UMR EEF, INRA, Nancy) for carbon, nitrogen and $\delta^{13} \mathrm{C}$ analysis, Christopher Baraloto (UMR Ecofog, Kourou) contributed to the delicate process of botanical identification and selection of the species while Jean-Yves Goret helped establish and maintain the experiment under the shading nets. Useful discussions with Eric Marcon, Christopher Baraloto and Heidy Schimann (UMR ECOFOG) and with Pierre Montpied and Daniel Epron (UMR EEF, INRA, Nancy) are gratefully acknowledged.

\section{References}

Baraloto C, Goldberg DE, Bonal D (2005) Performance trade-offs among tropical tree seedlings in contrasting microhabitats. Ecology 86, 2461-2472. doi:10.1890/04-1956

Bazzaz FA, Pickett STA (1980) Physiological ecology of tropical succession: a comparative review. Annual Review of Ecology and Systematics 11, 287-310. doi:10.1146/annurev.es.11.110180.001443

Bernacchi CJ, Singsaas EL, Pimentel C, Portis AR Jr, Long SP (2001) Improved temperature response functions for models of Rubiscolimited photosynthesis. Plant, Cell \& Environment 24, 253-259. doi:10.1111/j.1365-3040.2001.00668.x

Bloor JMG, Grubb PJ (2003) Growth and mortality in high and low light: trends among 15 shade-tolerant tropical rain forest tree species. Journal of Ecology 91, 77-85. doi:10.1046/j.1365-2745.2003.00743.x

Bloor JMG, Grubb PJ (2004) Morphological plasticity of shade-tolerant tropical rainforest tree seedlings exposed to light changes. Functional Ecology 18, 337-348. doi:10.1111/j.0269-8463.2004.00831.x

Bonal D, Born C, Brechet C, Coste S, Marcon E, Roggy J-C, Guehl JM (2007) The successional status of tropical rainforest tree species is associated with differences in leaf carbon isotope discrimination and functional traits. Annals of Forest Science 64, 169-176. doi:10.1051/forest:2006101

Bradshaw AD (1965) Evolutionary significance of phenotypic plasticity in plants. Advances in Genetics 13, 115-155. doi:10.1016/S0065-2660(08) 60048-6

Cernusak LA, Aranda J, Marshall JD, Winter K (2007) Large variation in whole-plant water-use efficiency among tropical tree species. New Phytologist 173, 294-305. doi:10.1111/j.1469-8137.2006.01913.x

Cornelissen JHC, Lavorel S, Garnier E, Diaz S, Buchmann N, et al. (2003) A handbook of protocols for standardised and easy measurement of plant functional traits worldwide. Australian Journal of Botany 51, 335-380. doi:10.1071/BT02124

Coste S, Roggy J-C, Imbert P, Born C, Bonal D, Dreyer E (2005) Leaf photosynthetic traits of 14 tropical rain forest species in relation to leaf nitrogen concentration and shade tolerance. Tree Physiology 25, $1127-1137$.

Coste S, Baraloto C, Leroy C, Marcon E, Renaud A, Richardson AD, Roggy JC, Schimann H, Uddling J, Hérault B (2010) Assessing foliar chlorophyll contents with the SPAD-502 chlorophyll meter: a calibration test with thirteen tree species of tropical rainforest in French Guiana. Annals of Forest Science, in press.

Ethier GJ, Livingston N (2004) On the need to incorporate sensitivity to $\mathrm{CO}_{2}$ transfer conductance into the Farquhar-von Caemmerer-Berry leaf photosynthesis model. Plant, Cell \& Environment 27, 137-153. doi:10.1111/j.1365-3040.2004.01140.x

Evans JR, von Caemmerer S (1996) Update on photosynthesis: carbon dioxide diffusion inside the leaves. Plant Physiology 110, 339-346.

Evans JR, Kaldenhoff R, Genty B, Terashima I (2009) Resistances along the $\mathrm{CO}_{2}$ diffusion pathway inside leaves. Journal of Experimental Botany 60, 2235-2248. doi:10.1093/jxb/erp117

Farquhar GD, Richards RA (1984) Isotopic composition of plant carbon correlates with water-use efficiency in wheat genotypes. Australian Journal of Plant Physiology 11, 539-552. doi:10.1071/PP9840539

Farquhar GD, von Caemmerer S, Berry JA (1980) A biochemical model of photosynthetic $\mathrm{CO}_{2}$ assimilation in leaves of $\mathrm{C}_{3}$ species. Planta 149 , 78-90. doi:10.1007/BF00386231

Fetcher N, Strain BR, Oberbauer SF (1983) Effects of light regime on the growth, leaf morphology, and water relations of seedlings of two species of tropical trees. Oecologia 58, 314-319. doi:10.1007/BF00385229

Frak E, Le Roux X, Millard P, Dreyer E, Jaouen G, Saint-Joanis B, Wendler R (2001) Changes in total leaf nitrogen and partitioning of leaf nitrogen drive photosynthetic acclimation to light in fully developed walnut leaves. Plant, Cell \& Environment 24, 1279-1288. doi:10.1046/ j.0016-8025.2001.00784.x 
Givnish TJ (1988) Adaptation to sun and shade: a whole plant perspective. Australian Journal of Plant Physiology 15, 63-92. doi:10.1071/ PP9880063

Givnish TJ, Montgomery RA, Goldstein G (2004) Adaptive radiation of photosynthetic physiology in the Hawaiian lobeliads: light regimes, static light responses, and whole-plant compensation points. American Journal of Botany 91, 228-246. doi:10.3732/ajb.91.2.228

Le Roux X, Grand S, Dreyer E, Daudet FA (1999) Parameterization and testing of a biochemically based photosynthesis model for walnut trees (Juglans regia) and seedlings. Tree Physiology 19, 481-492.

Lusk CH, Reich PB, Montgomery RA, Ackerly DD, Cavender-Bares J (2008) Why are evergreen leaves so contrary about shade? Trends in Ecology \& Evolution 23, 299-303. doi:10.1016/j.tree.2008.02.006

Markesteijn L, Poorter L, Bongers F (2007) Light-dependent leaf trait variation in 43 tropical dry forest species. American Journal of Botany 94, 515-525. doi:10.3732/ajb.94.4.515

Meir P, Kruijt B, Broadmeadow M, Barbosa E, Kull O, Carswell F, Nobre A, Jarvis PG (2002) Acclimation of photosynthetic capacity to irradiance in tree canopies in relation to leaf nitrogen concentration and leaf mass per unit area. Plant, Cell \& Environment 25, 343-357. doi:10.1046/j.00168025.2001.00811.x

Miner BG, Sultan SE, Morgan SG, Padilla DK, Relyea RA (2005) Ecological consequences of phenotypic plasticity. Trends in Ecology \& Evolution 20 , 685-692. doi:10.1016/j.tree.2005.08.002

Molino J-F, Sabatier D (2001) Tree diversity in tropical rain forests: a validation of the intermediate disturbance hypothesis. Science 294, 1702-1704. doi:10.1126/science.1060284

Montpied P, Granier A, Dreyer E (2009) Seasonal time-course of gradients of photosynthetic capacity and mesophyll conductance to $\mathrm{CO}_{2}$ across a beech (Fagus sylvatica L.) canopy. Journal of Experimental Botany 60, 2407-2418. doi:10.1093/jxb/erp093

Nicotra A, Chazdon RL, Schlichting CD (1997) Patterns of genotypic variation and phenotypic plasticity of light responses in two tropical Piper (Piperaceae) species. American Journal of Botany 84, 1542-1552. doi: $10.2307 / 2446616$

Niinemets Ü (2006) The controversy over traits conferring shade-tolerance in trees: ontogenetic changes revisited. Journal of Ecology 94, 464-470. doi:10.1111/j.1365-2745.2006.01093.x

Niinemets Ü, Tenhunen JD (1997) A model separating leaf structural and physiological effects on carbon gain along light gradients for the shade tolerant species Acer saccharum. Plant, Cell \& Environment 20, 845-866. doi:10.1046/j.1365-3040.1997.d01-133.x

Piel C, Frak E, Le Roux X, Genty B (2002) Effect of local irradiance on $\mathrm{CO}_{2}$ transfer conductance of mesophyll in walnut. Journal of Experimental Botany 53, 2423-2430. doi:10.1093/jxb/erf095

Pons TL, Pearcy RW (1994) Nitrogen reallocation and photosynthetic acclimation in response to partial shading in soybean plants. Physiologia Plantarum 92, 636-644. doi:10.1111/j.1399-3054.1994. tb03034.x

Poorter L (2007) Are species adapted to their regeneration niche, adult niche, or both? American Naturalist 169, 433-442. doi:10.1086/512045

Poorter H, Evans JR (1998) Photosynthetic nitrogen-use efficiency of species that differ inherently in specific leaf area. Oecologia 116, 26-37. doi: $10.1007 / \mathrm{s} 004420050560$

Poorter L, Werger MJA (1999) Light environment, sapling architecture, and leaf display in six rain forest tree species. American Journal of Botany $\mathbf{8 6}$, 1464-1473. doi:10.2307/2656927

Poorter L, Oberbauer SF, Clark DB (1995) Leaf optical properties along a vertical gradient in a tropical rain forest canopy in Costa Rica. American Journal of Botany 82, 1257-1263. doi:10.2307/2446248

Poorter H, Niinemets Ü, Poorter L, Wright IJ, Villar R (2009) Causes and consequences of variation in leaf mass per area (LMA): a meta-analysis. New Phytologist 182, 565-588. doi:10.1111/j.1469-8137.2009.02830.x
Popma J, Bongers F, Werger MJA (1992) Gap-dependence and leaf characteristics of trees in a tropical lowland rain forest in Mexico. Oikos 63, 207-214. doi:10.2307/3545380

Reich PB, Walters MB (1994) Photosynthesis-nitrogen relations in Amazonian tree species. II: Variation in nitrogen vis-a-vis specific leaf area influences mass and area-based expressions. Oecologia 97, 73-81. doi:10.1007/BF00317910

Reich PB, Ellsworth DS, Walters MB, Vose JM, Gresham C, Volin JC, Bowman WD (1999) Generality of leaf trait relationships: a test across six biomes. Ecology 80, 1955-1969.

Rice SA, Bazzaz FA (1989) Growth consequences of plasticity of plant traits in response to light conditions. Oecologia 78, 508-512. doi:10.1007/ BF00378742

Rijkers T, Pons TL, Bongers F (2000) The effect of tree height and light availability on photosynthetic leaf traits of four neotropical species differing in shade tolerance. Functional Ecology 14, 77-86. doi:10.1046/j.1365-2435.2000.00395.x

Roggy J-C, Nicolini E, Imbert P, Caraglio Y, Bosc A, Heuret P (2005) Links between tree structure and functional leaf traits in the tropical forest tree Dicorynia guianensis Amshoff (Caesalpiniaceae). Annals of Forest Science 62, 553-564. doi:10.1051/forest:2005048

Roussel M, Dreyer E, Montpied P, Le Provost G, Guehl JM, Brendel O (2009) The diversity of ${ }^{13} \mathrm{C}$ isotope discrimination in a Quercus robur full-sib family is associated with differences in intrinsic water use efficiency, transpiration efficiency, and stomatal conductance. Journal of Experimental Botany 60, 2419-2431. doi:10.1093/jxb/erp100

Rozendaal DMA, Hurtado VH, Poorter L (2006) Plasticity in leaf traits of 38 tropical tree species in response to light; relationships with light demand and adult stature. Functional Ecology 20, 207-216. doi:10.1111/j.13652435.2006.01105.x

Strauss-Debenedetti S, Bazzaz FA (1996) Photosynthetic characteristics of tropical trees along successional gradients. In 'Tropical forest ecophysiology'. (Eds SS Mulkey, RL Chazdon, AP Smith) pp. 162-186. (Chapman and Hall: New York, USA)

Valladares F, Niinemets U (2008) Shade tolerance, a key plant feature of complex nature and consequences. Annual Review of Ecology and Systematics 39, 237-257. doi:10.1146/annurev.ecolsys.39.110707. 173506

Valladares F, Wright SJ, Lasso E, Kitajima K, Pearcy RW (2000) Plastic phenotypic response to light of 16 congeneric shrubs from a Panamanian rainforest. Ecology 81, 1925-1936.

Valladares F, Sanchez-Gomez D, Zavala MA (2006) Quantitative estimation of phenotypic plasticity: bridging the gap between the evolutionary concept and its ecological applications. Journal of Ecology 94, 1103-1116. doi:10.1111/j.1365-2745.2006.01176.x

Warren CR, Adams MA (2006) Internal conductance does not scale with photosynthetic capacity: implications for carbon isotope discrimination and the economics of water and nitrogen use in photosynthesis. Plant, Cell \& Environment 29, 192-201. doi:10.1111/j.1365-3040.2005.01412.x

Warren CR, Dreyer E, Adams MA (2003) Photosynthesis-Rubisco relationships in foliage of Pinus sylvestris in response to nitrogen supply and the proposed role of Rubisco and amino acids as nitrogen stores. Trees - Structure and Function 17, 359-366.

Wright IJ, Reich PB, Westoby M, Ackerly DD, Baruch Z, et al. (2004) The worldwide leaf economics spectrum. Nature 428, 821-827. doi:10.1038/nature02403

Wright IJ, Reich PB, Cornelissen JHC, Falster DS, Garnier E, et al. (2005) Assessing the generality of global leaf trait relationships. New Phytologist 166, 485-496. doi:10.1111/j.1469-8137.2005.01349.x

Manuscript received 25 May 2009, accepted 11 January 2010 
Appendix 1. Abbreviations and symbols used in the text along with their units

\begin{tabular}{|c|c|c|}
\hline & Definition & Units \\
\hline \multicolumn{3}{|c|}{ Structural traits } \\
\hline LMA & Leaf mass per unit leaf area & $\mathrm{g} \mathrm{m}^{-2}$ \\
\hline Thickness & Leaf thickness & $\mu \mathrm{m}$ \\
\hline Density & Leaf density (LMA/thickness) & $\mathrm{g} \mathrm{cm}^{-3}$ \\
\hline LDMC & Leaf dry mater content (leaf dry mass/fresh mass) & $\mathrm{mg} \mathrm{g}^{-1}$ \\
\hline$C_{\mathrm{m}}$ & Total leaf carbon content ${ }^{\mathrm{A}}$ & $\mathrm{mg} \mathrm{g}^{-1}$ \\
\hline$N_{\mathrm{m}} ; N_{\mathrm{a}}$ & Total leaf nitrogen content ${ }^{\mathrm{A}}$ & $\mathrm{mg} \mathrm{g}^{-1} ; \mathrm{mg} \mathrm{m}^{-2}$ \\
\hline 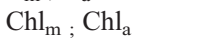 & Total leaf chlorophyll content ${ }^{\mathrm{A}}$ & $\mu \mathrm{mol} \mathrm{Chl} \mathrm{g}{ }^{-1} ; \mu \mathrm{mol} \mathrm{Chl} \mathrm{\textrm {m } ^ { - 2 }}$ \\
\hline \multicolumn{3}{|c|}{ Physiological traits } \\
\hline$V_{\text {cmax }} \mathrm{m} ; V_{\text {cmax }} \mathrm{a}$ & Maximal Rubisco activity $^{\mathrm{A}}$ & $\mathrm{nmol} \mathrm{CO} 2 \mathrm{~g}^{-1} \mathrm{~s}^{-1} ; \mu \mathrm{mol} \mathrm{CO} \mathrm{m}^{-2} \mathrm{~s}^{-1}$ \\
\hline$J_{\max } \mathrm{m} ; J_{\max } \mathrm{a}$ & Maximal electron transport rate ${ }^{\mathrm{A}}$ & $\mathrm{nmol} \mathrm{e} \mathrm{e}^{-1} \mathrm{~s}^{-1} ; \mu \mathrm{mol} \mathrm{e} \mathrm{e}^{-} \mathrm{m}^{-2} \mathrm{~s}^{-1}$ \\
\hline$R_{\mathrm{d}} \mathrm{m} ; R_{\mathrm{d}} \mathrm{a}$ & $\mathrm{CO}_{2}$ production by non photorespiratory respiration ${ }^{\mathrm{A}}$ & $\mathrm{nmol} \mathrm{CO} 2 \mathrm{~g}^{-1} \mathrm{~s}^{-1} ; \mu \mathrm{mol} \mathrm{CO} \mathrm{m}^{-2} \mathrm{~s}^{-1}$ \\
\hline$A_{\mathrm{sat}} \mathrm{m} ; A_{\mathrm{sat}} \mathrm{a}$ & Light saturated net assimilation rate $\mathrm{A}^{\mathrm{A}}$ & $\mathrm{nmol} \mathrm{CO} \mathrm{g}^{-1} \mathrm{~s}^{-1} ; \mu \mathrm{mol} \mathrm{CO} \mathrm{m}^{-2} \mathrm{~s}^{-1}$ \\
\hline$V_{\text {cmax }} / \mathrm{N}$ & Carboxylation rate per unit nitrogen & $\mu \mathrm{mol} \mathrm{CO} \mathrm{mmol}^{-1} \mathrm{~N} \mathrm{~s}^{-1}$ \\
\hline$J_{\max } / \mathrm{N}$ & Electron transport capacity per unit nitrogen & $\mu \mathrm{mol} \mathrm{CO} \mathrm{mmol}^{-1} \mathrm{~N} \mathrm{~s}^{-1}$ \\
\hline$A_{\text {sat }} / \mathrm{N}$ & Photosynthetic nitrogen-use efficiency (PNUE) & $\mu \mathrm{mol} \mathrm{CO} \mathrm{mmol}^{-1} \mathrm{~N} \mathrm{~s}^{-1}$ \\
\hline $\mathrm{Chl} / \mathrm{N}$ & Investment of leaf nitrogen in chlorophyll & 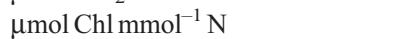 \\
\hline$\delta^{13} \mathrm{C}$ & Leaf carbon isotope composition & $\%$ \\
\hline$g_{\mathrm{s}}$ & Stomatal conductance for water vapour & $\mathrm{mmol} \mathrm{H}_{2} \mathrm{O} \mathrm{m}^{-2} \mathrm{~s}^{-1}$ \\
\hline WUE $_{\mathrm{i}}$ & Intrinsic water use efficiency $\left(A_{\text {sat }} / g_{\mathrm{s}}\right)$ & $\mu \mathrm{mol} \mathrm{CO}{ }_{2} \mathrm{~mol}^{-1} \mathrm{H}_{2} \mathrm{O}$ \\
\hline RDPI & Relative distance plasticity index & \\
\hline
\end{tabular}

A'm' denotes mass-based and 'a' denotes area-based values. 
Appendix 2. Results from an ANOVA test for the effects of two factors: species (seven levels) and light (relative irradiance; three levels, $I_{5}, I_{10}$ and $I_{20}$ ) and their interaction on leaf structure and photosynthetic traits $n=5$ to 7 individuals per specie $\times$ irradiance regime. $F$-values and probability are displayed. With the exception of $\delta^{13} \mathrm{C}(\%), N_{\mathrm{a}}\left(\mathrm{g} \mathrm{m}^{-2}\right), N_{\mathrm{m}}\left(\mathrm{mg} \mathrm{g}^{-1}\right), C_{\mathrm{m}}\left(\mathrm{mg} \mathrm{g}^{-1}\right)$, LDMC $\left(\mathrm{mg} \mathrm{g}^{-1}\right), J_{\max }: V_{\text {cmax }}$ and $\mathrm{WUE}_{\mathrm{i}}\left(\mu \mathrm{mol} \mathrm{mol}{ }^{-1}\right)$, all variables were transformed as square roots for $R_{\mathrm{d}} \mathrm{a}$ or $\log _{10}$ for all other traits. Mean values $( \pm 95 \%$ confidence interval) are displayed for each irradiance level. For each trait, a Spearman rank coefficient is displayed for mean species values between the two extreme levels of irradiance $\left(\mathrm{t}_{5}\right.$ and $\mathrm{t}_{20}$ ). n.s., not significant, $P>0.05 ;{ }^{*} P<0.05 ;{ }^{* *} P<0.01 ;{ }^{* * *} P<0.001$

\begin{tabular}{|c|c|c|c|c|c|c|c|}
\hline & Species & $\begin{array}{c}\text { Light } \\
F \text {-value }\end{array}$ & $\mathrm{Sp} \times \mathrm{L}$ & $\mathrm{I}_{5}$ & $\begin{array}{c}\mathrm{I}_{10} \\
\text { Mean }\end{array}$ & $\mathrm{I}_{20}$ & Kendall's $\tau$ \\
\hline \multicolumn{8}{|c|}{ Structural traits } \\
\hline LMA $\left(\mathrm{g} \mathrm{m}^{-2}\right)$ & $98.8 * * *$ & $52.2 * * *$ & $2.67 * *$ & $41.5 \pm 5.1 \mathrm{a}$ & $51.1 \pm 6.6 \mathrm{~b}$ & $56.8 \pm 5.6 \mathrm{c}$ & $0.90 * *$ \\
\hline Thickness $(\mu \mathrm{m})$ & $169 * * *$ & $24.3 * * *$ & $1.9^{*}$ & $164 \pm 23 a$ & $186 \pm 22 b$ & $204 \pm 25 c$ & $0.90 * *$ \\
\hline Density $\left(\mathrm{g} \mathrm{cm}^{-3}\right)$ & $227 * * *$ & $25.4^{* * *}$ & 0.86 n.s. & $0.27 \pm 0.03 \mathrm{a}$ & $0.30 \pm 0.03 b$ & $0.31 \pm 0.04 b$ & $1.00 * * *$ \\
\hline $\operatorname{LDMC}\left(\mathrm{mg} \mathrm{g}^{-1}\right)$ & $122 * * *$ & $6.17^{* *}$ & $1.89^{*}$ & $331 \pm 28 \mathrm{a}$ & $348 \pm 28 \mathrm{ab}$ & $355 \pm 32 b$ & $0.90 * *$ \\
\hline$C_{\mathrm{m}}\left(\mathrm{mg} \mathrm{g}^{-1}\right)$ & $210 * * *$ & $15.4 * * *$ & $5.5^{* * *}$ & $449 \pm 11 \mathrm{a}$ & $460 \pm 8.9 b$ & $457 \pm 8.0$ & $0.81 * *$ \\
\hline$N_{\mathrm{a}}\left(\mathrm{mg} \mathrm{m}^{-2}\right)$ & $2.80 *$ & 2.97 n.s. & 0.89 n.s. & $0.96 \pm 0.05$ & $1.02 \pm 0.07$ & $1.07 \pm 0.06$ & 0.14 n.s. \\
\hline$N_{\mathrm{m}}\left(\mathrm{mg} \mathrm{g}^{-1}\right)$ & $72.6^{* * *}$ & $21.3^{* * *}$ & 1.49 n.s. & $25.9 \pm 2.6 \mathrm{a}$ & $22.3 \pm 2.5 b$ & $20.6 \pm 2.2 b$ & $0.90 * *$ \\
\hline $\mathrm{Chl}_{\mathrm{a}}\left(\mu \mathrm{mol} \mathrm{m}{ }^{-2}\right)$ & $23.9 * * *$ & $10.3^{* * *}$ & 1.18 n.s. & $581 \pm 51 \mathrm{a}$ & $617 \pm 66 a$ & $507 \pm 70 \mathrm{~b}$ & $0.62 *$ \\
\hline $\mathrm{Chl}_{\mathrm{m}}\left(\mu \mathrm{mol} \mathrm{g} \mathrm{g}^{-1}\right)$ & $22.9^{* * *}$ & $51.7^{* * *}$ & $2.14 *$ & $15.7 \pm 1.8 \mathrm{a}$ & $13.2 \pm 1.4 \mathrm{~b}$ & $9.29 \pm 1.2 \mathrm{c}$ & $0.52 \mathrm{n} . \mathrm{s}$ \\
\hline \multicolumn{8}{|c|}{ Physiological traits } \\
\hline$V_{\text {cmax }} \mathrm{a}\left(\mu \mathrm{mol} \mathrm{m}{ }^{-2} \mathrm{~s}^{-1}\right)$ & $29.8 * * *$ & $17.9^{* * *}$ & 0.29 n.s. & $31.7 \pm 4.4 \mathrm{a}$ & $37.5 \pm 5.0 \mathrm{~b}$ & $48.5 \pm 6.4 c$ & 0.52 n.s. \\
\hline$J_{\max } \mathrm{a}\left(\mu \mathrm{mol} \mathrm{m} \mathrm{m}^{-2} \mathrm{~s}^{-1}\right)$ & $30.9 * * *$ & $26.7 * * *$ & 0.99 n.s. & $45.2 \pm 4.8 \mathrm{a}$ & $52.2 \pm 7.6 \mathrm{a}$ & $77.4 \pm 12 b$ & $0.71 *$ \\
\hline$R_{\mathrm{d}} \mathrm{a}\left(\mu \mathrm{mol} \mathrm{m} \mathrm{m}^{-2} \mathrm{~s}^{-1}\right)$ & $10.1 * * *$ & $19.7 * * *$ & $2.46^{* *}$ & $0.39 \pm 0.09 \mathrm{a}$ & $0.45 \pm 0.10 \mathrm{a}$ & $0.95 \pm 0.24 \mathrm{~b}$ & 0.14 n.s. \\
\hline$V_{\text {cmax }} \mathrm{m}\left(\mathrm{nmol} \mathrm{g}^{-1} \mathrm{~s}^{-1}\right)$ & $75.1 * * *$ & 1.65 n.s. & 0.9 n.s. & $959 \pm 227$ & $874 \pm 210$ & $985 \pm 200$ & $0.71 *$ \\
\hline$J_{\max } \mathrm{m}\left(\mathrm{nmolg}^{-1} \mathrm{~s}^{-1}\right)$ & $94.2 * * *$ & $8.76^{* * *}$ & 1.25 n.s. & $1326 \pm 253 \mathrm{a}$ & $1158 \pm 282 b$ & $1593 \pm 354 \mathrm{a}$ & $0.71 *$ \\
\hline$R_{\mathrm{d}} \mathrm{m}\left(\mathrm{nmolg} \mathrm{g}^{-1} \mathrm{~s}^{-1}\right)$ & $22.1 * * *$ & $6.05^{* *}$ & 1.54 n.s. & $11.0 \pm 3.1 \mathrm{a}$ & $10.6 \pm 3.2 \mathrm{a}$ & $20.3 \pm 5.9 b$ & 0.52 n.s. \\
\hline$J_{\max }: V_{\mathrm{cmax}}$ & 1.57 n.s. & $5.09 * *$ & $1.86^{*}$ & $1.50 \pm 0.09 \mathrm{ab}$ & $1.40 \pm 0.06 \mathrm{a}$ & $1.58 \pm 0.08 \mathrm{~b}$ & -0.24 n.s. \\
\hline$A_{\mathrm{sat}} \mathrm{a}\left(\mu \mathrm{mol} \mathrm{m} \mathrm{m}^{-2} \mathrm{~s}^{-1}\right)$ & $33.4 * * *$ & $28.7 * * *$ & 0.4 n.s. & $4.55 \pm 0.5 \mathrm{a}$ & $5.39 \pm 0.7 \mathrm{~b}$ & $7.38 \pm 1.0$ & $0.71 *$ \\
\hline$A_{s \mathrm{at}} \mathrm{m}\left(\mathrm{nmol} \mathrm{g}^{-1} \mathrm{~s}^{-1}\right)$ & $84.4 * * *$ & $5.48^{* *}$ & 1.12 n.s. & $136 \pm 29 \mathrm{a}$ & $120 \pm 27 b$ & $150 \pm 31 \mathrm{a}$ & 0.52 n.s. \\
\hline$V_{\mathrm{cmax}}: \mathrm{N}\left(\mu \mathrm{mol} \mathrm{mmol}^{-1} \mathrm{~s}^{-1}\right)$ & $39.6 * * *$ & $15.6^{* * *}$ & 0.64 n.s. & $0.48 \pm 0.07 \mathrm{a}$ & $0.50 \pm 0.07 \mathrm{a}$ & $0.63 \pm 0.07 \mathrm{~b}$ & $0.52 \mathrm{n} . \mathrm{s}$. \\
\hline$J_{\max }: \mathrm{N}\left(\mu \mathrm{mol} \mathrm{mmol}{ }^{-1} \mathrm{~s}^{-1}\right)$ & $42.7 * * *$ & $31.0 * * *$ & 1.23 n.s. & $0.67 \pm 0.07 \mathrm{a}$ & $0.67 \pm 0.10 \mathrm{a}$ & $1 \pm 0.13 b$ & $0.62 *$ \\
\hline$A_{\text {sat }}: \mathrm{N}\left(\mu \mathrm{mol} \mathrm{mmol}{ }^{-1} \mathrm{~s}^{-1}\right)$ & $36.1 * * *$ & $24.6^{* * *}$ & 0.58 n.s. & $0.07 \pm 0.01 \mathrm{a}$ & $0.07 \pm 0.01 \mathrm{a}$ & $0.10 \pm 0.01 \mathrm{~b}$ & $0.81 * *$ \\
\hline $\mathrm{Chl}: \mathrm{N}\left(\mu \mathrm{mol} \mathrm{mmol}{ }^{-1}\right)$ & $27.5 * * *$ & $29.6^{* * *}$ & 1.41 n.s. & $8.69 \pm 0.6 \mathrm{a}$ & $8.75 \pm 0.8 \mathrm{a}$ & $6.72 \pm 1.1 \mathrm{~b}$ & $0.71 *$ \\
\hline$\delta^{13} \mathrm{C}(\% o)$ & $50.1 * * *$ & $33.2 * * *$ & 1.04 n.s. & $-31.8 \pm 0.7 \mathrm{a}$ & $-31.2 \pm 0.7 \mathrm{a}$ & $-29.7 \pm 0.7 b$ & $0.71 *$ \\
\hline$g_{\mathrm{s}}\left(\mathrm{mmol} \mathrm{m} \mathrm{s}^{-2} \mathrm{~s}^{-1}\right)$ & $25.4 * * *$ & $228 * * *$ & 0.59 n.s. & $89.8 \pm 15 \mathrm{a}$ & $108 \pm 27 \mathrm{a}$ & $177 \pm 46 b$ & $0.90^{* * *}$ \\
\hline 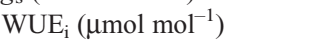 & $8.52 * * *$ & $7.33^{* * *}$ & 0.56 n.s. & $55.4 \pm 4.3 \mathrm{ab}$ & $60 \pm 4.9 \mathrm{a}$ & $48.6 \pm 5.6 b$ & $0.81 * *$ \\
\hline
\end{tabular}

